\title{
Additional oxidative stress reroutes the global response of Aspergillus fumigatus to iron depletion
}

Vivien Kurucz ${ }^{1}$, Thomas Krüger ${ }^{2}$, Károly Antal ${ }^{3}$, Anna-Maria Dietll ${ }^{4}$, Hubertus Haas ${ }^{4}$, István Pócsi ${ }^{1}$, Olaf Kniemeyer ${ }^{2^{*}}$ and Tamás Emri ${ }^{1^{*}}$ (D)

\begin{abstract}
Background: Aspergillus fumigatus has to cope with a combination of several stress types while colonizing the human body. A functional interplay between these different stress responses can increase the chances of survival for this opportunistic human pathogen during the invasion of its host. In this study, we shed light on how the $\mathrm{H}_{2} \mathrm{O}_{2}$-induced oxidative stress response depends on the iron available to this filamentous fungus, using transcriptomic analysis, proteomic profiles, and growth assays.

Results: The applied $\mathrm{H}_{2} \mathrm{O}_{2}$ treatment, which induced only a negligible stress response in iron-replete cultures, deleteriously affected the fungus under iron deprivation. The majority of stress-induced changes in gene and protein expression was not predictable from data coming from individual stress exposure and was only characteristic for the combination of oxidative stress plus iron deprivation. Our experimental data suggest that the physiological effects of combined stresses and the survival of the fungus highly depend on fragile balances between economization of iron and production of essential iron-containing proteins. One observed strategy was the overproduction of iron-independent antioxidant proteins to combat oxidative stress during iron deprivation, e.g. the upregulation of superoxide dismutase Sod1, the thioredoxin reductase Trr1, and the thioredoxin orthologue Afu5g11320. On the other hand, oxidative stress induction overruled iron deprivation-mediated repression of several genes. In agreement with the gene expression data, growth studies underlined that in A. fumigatus iron deprivation aggravates oxidative stress susceptibility.

Conclusions: Our data demonstrate that studying stress responses under separate single stress conditions is not sufficient to understand how A. fumigatus adapts in a complex and hostile habitat like the human body. The combinatorial stress of iron depletion and hydrogen peroxide caused clear non-additive effects upon the stress response of $A$. fumigatus. Our data further supported the view that the ability of $A$. fumigatus to cause diseases in humans strongly depends on its fitness attributes and less on specific virulence factors. In summary, A. fumigatus is able to mount and coordinate complex and efficient responses to combined stresses like iron deprivation plus $\mathrm{H}_{2} \mathrm{O}_{2}$-induced oxidative stress, which are exploited by immune cells to kill fungal pathogens.
\end{abstract}

Keywords: Aspergillus fumigatus, Combinatorial stress, Iron deprivation, Oxidative stress, Proteomics, Stress response, Transcriptomics

\footnotetext{
*Correspondence: olaf.kniemeyer@hki-jena.de; emri.tamas@science.unideb.hu

${ }^{2}$ Molecular and Applied Microbiology, Leibniz Institute for Natural Product

Research and Infection Biology - Hans Knöll Institute (HKI), 07745 Jena,

Germany

${ }^{1}$ Department of Biotechnology and Microbiology, Faculty of Sciences and

Technology, University of Debrecen, Egyetem tér 1, Debrecen $\mathrm{H}-4032$,

Hungary

Full list of author information is available at the end of the article
}

(c) The Author(s). 2018 Open Access This article is distributed under the terms of the Creative Commons Attribution 4.0 International License (http://creativecommons.org/licenses/by/4.0/), which permits unrestricted use, distribution, and reproduction in any medium, provided you give appropriate credit to the original author(s) and the source, provide a link to the Creative Commons license, and indicate if changes were made. The Creative Commons Public Domain Dedication waiver (http://creativecommons.org/publicdomain/zero/1.0/) applies to the data made available in this article, unless otherwise stated. 


\section{Background}

Aspergillus fumigatus is a ubiquitous fungal species, which occurs commonly on decaying organic matter and in soil under a wide variety of conditions [1, 2]. This mould is also known as one of the most important airborne human pathogenic fungi with an outstandingly high mortality rate (50-95\%) in immunocompromised patients, who suffer from an invasive $A$. fumigatus infection (referred to as invasive aspergillosis) [3-6]. The reasons for the unique success of $A$. fumigatus as the most important opportunistic human pathogen among phylogenetically closely related aspergilli are largely unknown.

Several fungal factors that determine the outcome of infections have been identified [6-10]. These include the rodlet and cell wall melanin layers of conidia $[11,12]$; the cell wall exopolysaccharide galactosaminogalactan, which has possible anti-inflammatory effects [13]; the production of mycotoxins such as the immune response modulator gliotoxin [14]; elastinolytic proteases [15]; efficient iron and zinc acquisition systems [16, 17]; acquisition and detoxification of copper [18, 19]; as well as the suitable oxidative stress defense systems to detoxify reactive oxygen species (ROS) generated by macrophages and neutrophils [10, 20].

The stress responses of $A$. fumigatus have also been studied intensively in order to identify a potential Achilles' heel of this pathogen. Researchers aimed to elucidate the orchestration of the signaling network regulating the stress response and understanding the physiological background of the adaptation process [21-29]. Iron starvation and oxidative stress are typical stresses for $A$. fumigatus and also for other microorganisms, which they may encounter in the human host [29]. A. fumigatus acquires iron by low affinity iron transporters, the reductive iron assimilation (RIA) system, and siderophore-mediated iron uptake [30]. It is unable to utilize iron directly from human iron-binding proteins like hemoglobin, transferrin, or ferritin [30], however siderophores can chelate iron from host proteins [31]. The significance of the low affinity iron transport has not been studied in details so far [29, 30]. Both RIA and siderophoremediated iron uptake are important in adaptation to iron starvation, however, only the contribution of siderophore biosynthesis and ferri-siderophore transport to virulence has been demonstrated until now [30, 32-34]. The transcription factor HapX is crucial in regulating the iron starvation stress response in A. fumigatus [35]. It down-regulates iron-consuming pathways such as ironsulfur cluster assembly, heme biosynthesis, respiration, the tricarboxylic-acid (TCA) cycle and amino acid metabolism, while it up-regulates iron acquisition via siderophore biosynthesis [35].
Several elements of the oxidative stress response have been identified in $A$. fumigatus, which include the production of catalases, superoxide dismutases (SODs), elements of the thioredoxin and glutathioneglutaredoxin system, as well as the conidial pigment melanin [12, 26]. Both MpkA- and SakA-mediated MAPK stress signaling pathways as well as the Yap1 and Skn7 transcriptional regulators were demonstrated to modulate the oxidative stress response [3639]. Single gene deletions had no impact on virulence, suggesting that a significant level of redundancy exists in the oxidative stress defense system of $A$. fumigatus [29]. Importantly, oxidative stress response and iron metabolism are tightly linked; iron overload can catalyze the formation of ROS, but detoxification of ROS by heme peroxidases and catalases requires the iron-containing cofactor heme [40, 41].

In natural habitats like the human body, microbial pathogens have to cope with combinations of various and rapidly changing stress conditions rather than single stress types. The interplay between different stress responses can decrease synergistically and markedly the fitness and, hence, the chance of the microorganisms to survive in the host. Indeed, human polymorphonuclear leukocytes have been shown to inhibit fungal growth by oxidative and non-oxidative mechanisms including iron depletion mediated via lactoferrin $[42,43]$.

Here, we examined how $A$. fumigatus adapts to combined stresses (iron deprivation/oxidative stress: $-\mathrm{Fe} /+\mathrm{H}_{2} \mathrm{O}_{2}$ ) at the level of transcriptome and proteome. For this purpose, we compared the early stress responses to $\mathrm{H}_{2} \mathrm{O}_{2}$-induced oxidative stress in both iron-deprived and iron-replete $A$. fumigatus cultures. Oxidative and iron deficiency stress were chosen for two reasons: i) fungal pathogen species have to face both of them concomitantly in the human body [16, 26], and ii) combating these combined stresses is likely a difficult situation for the fungus to handle because iron is an important cofactor for several antioxidant enzymes such as catalases and heme peroxidases [40, 41] and, hence, a synergism between iron deprivation and oxidative stresses is predictable. To get comprehensive insights into the stress responses of iron-deprived A. fumigatus cultures towards ROS, we used a combined transcriptomic-proteomic based approach. Another reason for this is the fact that transcriptional changes do not necessarily correspond to changes in the protein concentrations [44]. This may be particularly true to iron-deprived conditions: upregulation of an iron-dependent enzyme at the transcriptional level may not necessarily result in an increased abundance of the corresponding protein due to the lack of iron cofactors. 


\section{Methods}

\section{Strain and growth conditions}

A. fumigatus strain Af293 (CBS 101355), received from the CBS-KNAW culture collection (http://www.westerdijkinstitute.nl/Collections/), was used throughout this study with exception of the oxidative stress resistance analysis and was maintained on Barrat's minimal nitrate agar plates [45]. Plates were incubated at $37{ }^{\circ} \mathrm{C}$ for $5 \mathrm{~d}$. Conidia obtained from the 5-days-old cultures were used in these experiments. Modified Barrat's minimal nitrate broths (100 $\mathrm{ml}$ in $500 \mathrm{ml}$ flasks) were inoculated with freshly isolated conidia and were incubated at $37{ }^{\circ} \mathrm{C}$ and $3.7 \mathrm{~Hz}$ shaking frequency. The modified Barrat's minimal nitrate broth differed from the standard Barrat's minimal nitrate medium in the added trace element solution, which did not contain EDTA and iron. This modified form of Barrat's minimal nitrate broth was either supplemented with $30 \mu \mathrm{M} \mathrm{FeCl}$ (+Fe; iron-replete cultures) or used without addition of any iron (-Fe; iron-depleted cultures). Cultures (+Fe and -Fe) were inoculated with $4 \times 10^{8}$ and $8 \times 10^{8}$ conidia and were incubated for $33 \mathrm{~h}$ and $50 \mathrm{~h}$, respectively, before harvest. At the two time points, the $+\mathrm{Fe}$ and -Fe cultures showed similar residual glucose content as well as similar dry cell mass. Oxidative stress was induced by addition of $\mathrm{H}_{2} \mathrm{O}_{2}$ (at $3 \mathrm{mM}$ final concentration) to the cultures $1 \mathrm{~h}$ before sampling $\left(+\mathrm{H}_{2} \mathrm{O}_{2}\right.$ and $-\mathrm{H}_{2} \mathrm{O}_{2}$ cultures).

For analysis of oxidative stress resistance, A. fumigatus strain ATCC 46645 (wild-type strain with similar oxidative stress resistance to the AF293 strain) and its siderophore-deficient derivative $(\Delta \operatorname{sid} A)$ [30] were used. Strains $\left(10^{4}\right.$ conidia) were point-inoculated on minimal agar plates with different iron supply (30 $\mu \mathrm{M} \mathrm{FeSO}_{4}$ or without addition of iron) with and without agents for inducing oxidative stress (1-3 mM $\mathrm{H}_{2} \mathrm{O}_{2}, 0.5-2 \mathrm{mM}$ paraquat or $0.01-0.03 \mathrm{mM}$ menadione). Notably, ferrous iron is quickly oxidized to ferric iron during aerobic conditions, and we did not observe differences in growth patterns between supplementation with ferrous $\left(\mathrm{FeSO}_{4}\right)$ compared to ferric $\left(\mathrm{FeCl}_{3}\right)$ iron (data not shown). Certain plates also contained $0.2 \mathrm{mM}$ bathophenanthroline disulfonate (BPS), a ferrous iron-specific chelator, which inactivates reductive iron assimilation [30]. All experiments were carried out in triplicates and growth was scored after incubation for $48 \mathrm{~h}$ at $37{ }^{\circ} \mathrm{C}$.

\section{2',7'-dichlorofluorescin diacetate and chrome azurol S (CAS) liquid assays}

In order to test how stress treatments perturb the redox homeostasis and siderophore production of cells, the following assays were applied: formation of $2^{\prime}, 7^{\prime}$-dichlorofluorescein (DCF) from 2',7'-dichlorofluorescin diacetate, a marker of redox imbalance, was recorded as described previously
[46]. The siderophore content of the fermentation broth was measured by the CAS liquid assay according to Machuca and Milagres [47].

\section{Reverse-transcription quantitative real-time polymerase chain reaction (RT-qPCR) assays}

Total RNA was isolated from lyophilized mycelia according to Chomczynski [48]. RT-qPCR experiments were carried out as described previously [49] with the primer pairs presented in Additional file 1. RT-qPCR assays were carried out at the Genomic Medicine and Bioinformatics Core Facility, Department of Biochemistry and Molecular Biology, Faculty of Medicine, University of Debrecen, Debrecen, Hungary. The $\Delta \Delta C P$ values were used to quantify relative transcription levels and the gene Afu6g12400 ( $f k s 1)$ was selected as reference.

\section{RNA sequencing}

Total RNA was isolated from $+\mathrm{Fe} /-\mathrm{H}_{2} \mathrm{O}_{2}$ (iron-replete), $+\mathrm{Fe} /+\mathrm{H}_{2} \mathrm{O}_{2} \quad\left(\mathrm{H}_{2} \mathrm{O}_{2}\right.$-treated), $-\mathrm{Fe} /-\mathrm{H}_{2} \mathrm{O}_{2}$ (iron-deprived), and $-\mathrm{Fe} /+\mathrm{H}_{2} \mathrm{O}_{2}$ (iron-deprived- $\mathrm{H}_{2} \mathrm{O}_{2}$-treated) cultures in three biological replicates as described previously [48]. RNA samples were isolated for RNA sequencing and for RT-qPCR from independent experiments. RNAsequencing (from library preparation to generation of fastq.gz files) was carried out at the Genomic Medicine and Bioinformatic Core Facility, Department of Biochemistry and Molecular Biology, Faculty of Medicine, University of Debrecen, Debrecen, Hungary. cDNA libraries for RNA-Seq were generated from $1 \mu \mathrm{g}$ total RNA using a TruSeq RNA Sample Preparation Kit (Illumina, San Diego, CA, USA) according to the manufacturer's protocol. Fragment size distribution and molarity of libraries were checked on Agilent BioAnalyzer DNA1000 chip (Agilent Technologies, Santa Clara, CA, USA). A single-read 50 bp sequencing run was performed on an Illumina HiScan SQ instrument (Illumina, San Diego, CA, USA). Each library pool was sequenced in one lane of a sequencing flow cell, and 16-18 million reads per sample were obtained. The CASAVA software was used for pass filtering and demultiplexing processing.

Reads were aligned to A fumigatus (Af293) genome (Genome: A_fumigatus_Af293_version_s03-m05-r04_ chromosomes.fasta.gz; http://www.aspergillusgenome. org/download/sequence/A_fumigatus_Af293/archive; Genome features file (GFF): A_fumigatus_Af293_version_ s03-m05-r04_features_with_chromosome_sequences.gff.gz; http://www.aspergillusgenome.org/download/gff/A_fumigatus_Af293/archive) using tophat (version 2.0.9) [50]. Calculation of FPKM (fragments per kilobase per million mapped fragments) values at the gene level and differential gene expression testing was performed using cuffdiff (version 2.2.1) [51] based on the mappings and corresponding genome features. 


\section{Evaluation of transcriptome data}

Up-regulated, down-regulated, and stress responsive genes were defined as genes that showed significantly different expression in the three biological replicates employing the cuffdiff software (version 2.2.1) [51] (adjusted $p$-value $<0.05$ ) and where the transcriptional difference was at least two-fold: $\log _{2} \mathrm{FC}>1$ (up-regulated genes), $\log _{2} \mathrm{FC}<-1$ (down-regulated genes) or $\left|\log _{2} \mathrm{FC}\right|>$ 1 (stress responsive genes), where FC ("fold-change") stands for $I_{\text {treated }} / I_{\text {reference }}$ and I is the mean FPKM value).

\section{Proteomics sample preparation}

Three biological replicates of A. fumigatus Af293 mycelium samples from four different growth conditions were measured as described above in the section "Strain and growth conditions". These included ironreplete conditions with $\left(+\mathrm{Fe} /+\mathrm{H}_{2} \mathrm{O}_{2}\right)$ and without $\left(+\mathrm{Fe} /-\mathrm{H}_{2} \mathrm{O}_{2}\right)$ oxidative stress induced by $3 \mathrm{mM}$ hydrogen peroxide, as well as iron-deprived conditions with $\left(-\mathrm{Fe} /+\mathrm{H}_{2} \mathrm{O}_{2}\right)$ and without $\left(-\mathrm{Fe} /-\mathrm{H}_{2} \mathrm{O}_{2}\right)$ oxidative stress. Proteins were isolated and digested as described previously [52]. Labeling of tryptic peptides with iTRAQ 4-plex (Sciex, Darmstadt, Germany) reagents was performed according to the manufacturer's manual. Each biological replicate was represented in one 4-plex reaction. The three 4-plex reactions were made up as follows: $114\left(+\mathrm{Fe} \# 1 ;-\mathrm{Fe} /+\mathrm{H}_{2} \mathrm{O}_{2} \# 2 ;+\mathrm{Fe} /+\mathrm{H}_{2} \mathrm{O}_{2} \# 3\right)$, $115\left(-\mathrm{Fe} \# 1 ;+\mathrm{Fe} \# 2 ;-\mathrm{Fe} /+\mathrm{H}_{2} \mathrm{O}_{2} \# 3\right), 116\left(+\mathrm{Fe} /+\mathrm{H}_{2} \mathrm{O}_{2}\right.$ $\# 1 ;-\mathrm{Fe} \# 2 ;+\mathrm{Fe} \# 3), 117\left(-\mathrm{Fe} /+\mathrm{H}_{2} \mathrm{O}_{2} \# 1 ;+\mathrm{Fe} /+\mathrm{H}_{2} \mathrm{O}_{2}\right.$ $\# 2$; -Fe \#3). Each 4-plex reaction was combined, dried (speed vac), and resolubilized in $40 \mu \mathrm{L}$ of $0.05 \%(\mathrm{v} / \mathrm{v})$ trifluoroacetic acid in 2/98 (v/v) acetonitrile (ACN)/ $\mathrm{H}_{2} \mathrm{O}$ for LC-MS/MS analysis.

\section{Liquid chromatography coupled to tandem mass spectrometry (LC-MS/MS) analysis}

Proteome analysis was performed on an Ultimate 3000 nano RSLC/QExactive Plus LC-MS/MS system (Thermo Fisher Scientific). Each 4-plex reaction was measured in triplicate with an injection volume of $4 \mu \mathrm{L}$. Peptides were measured as described previously [52] including the following changes: The mobile phase consisted of eluent A $\left[0.1 \%(\mathrm{v} / \mathrm{v})\right.$ formic acid in $\left.\mathrm{H}_{2} \mathrm{O}\right]$ and eluent $\mathrm{B}$ $\left[0.1 \%(\mathrm{v} / \mathrm{v})\right.$ formic acid in a ratio of $\left.90 / 10 \mathrm{ACN} / \mathrm{H}_{2} \mathrm{O}\right]$. Gradient elution was $0-4 \mathrm{~min}$ at $4 \% \mathrm{~B}, 150 \mathrm{~min}$ at $14 \%$ B, $200 \mathrm{~min}$ at $19 \% \mathrm{~B}, 300 \mathrm{~min}$ at $42 \% \mathrm{~B}, 319-329 \mathrm{~min}$ at $90 \% \mathrm{~B}$, and $330-400 \mathrm{~min}$ at $4 \% \mathrm{~B}$. Higher-energy collisional dissociation (HCD) fragmentation with the help of nitrogen gas occurred at a normalized collision energy of $34 \mathrm{~V}$. Dynamic exclusion of precursor ions was set to $35 \mathrm{~s}$ and the fixed first mass was set to $\mathrm{m} / \mathrm{z} 110$ to match the iTRAQ reporter ions (m/z 114-117).
Protein database search and reporter ion quantification Thermo raw files were processed by Proteome Discoverer 1.4 (Thermo). MS/MS spectra were searched against the AspGD protein database of A. fumigatus Af293 (www. aspergillusgenome.org/download/sequence/A_fumigatus_ Af293/current/A_fumigatus_Af293_current_orf_trans_all. fasta.gz; [53]) using Mascot 2.4 (Matrix Science, UK), Sequest HT and MS Amanda including up to two missed tryptic cleavages, a precursor mass tolerance of $10 \mathrm{ppm}$, and a fragment mass tolerance of 0.02 Da. Dynamic modifications were oxidation of Met and iTRAQ labeling of Tyr residues (not considered for quantification). Static modifications were carbamidomethylation of Cys by iodoacetamide and ITRAQ labeling of Lys residues and the peptide $\mathrm{N}$-terminus. At least 2 peptides per protein and a strict target false discovery rate of $<1 \%$ were required for positive protein hits. Reporter ion quantification was based on an integration tolerance of $10 \mathrm{ppm}$ using the most confident centroid. Reporter ion ratios were calculated for each 4-plex reaction based on the following comparisons: $-\mathrm{Fe} /+\mathrm{Fe},+\mathrm{Fe}+\mathrm{H}_{2} \mathrm{O}_{2} /+\mathrm{Fe}$, $-\mathrm{Fe}+$ $\mathrm{H}_{2} \mathrm{O}_{2} /+\mathrm{Fe},-\mathrm{Fe}+\mathrm{H}_{2} \mathrm{O}_{2} /+\mathrm{Fe}+\mathrm{H}_{2} \mathrm{O}_{2}$, $-\mathrm{Fe}+\mathrm{H}_{2} \mathrm{O}_{2} /$-Fe. Only unique peptides were considered for quantification. Isotopic correction and protein median normalization was applied. The significance threshold for iTRAQ ratios were $\geq 1.5$ (up- or down). The data was further manually evaluated based on the average reporter ion count ( $\geq 2$ for medium confidence, $\geq 4$ for high confidence). Furthermore, the average variability was observed as a function of the differential regulation and the precursor ion count.

\section{Functional annotation of transcriptome and proteome data}

The FungiFun2 package (https://elbe.hki-jena.de/fungifun/fungifun.php), with default settings was used to test the enrichment of genes related to FunCat and KEGG pathway categories in stress responsive gene groups [53]. Enrichment analysis was also carried out with the AspGD Gene Ontology Term Finder (http://www.aspergillusgenome.org/cgi-bin/GO/goTermFinder; [54]) applying default settings and biological process ontology GO terms. Only hits with $p$-value $<0.05$ were taken into consideration during the evaluation process. Protein enrichment analysis was carried out as described above using the appropriate gene IDs instead of protein IDs.

Fisher's exact test $(p<0.05)$ was used to detect significant gene enrichment of the following gene/protein groups in the stress responsive gene sets:

(1) Antioxidant enzymes. This group of proteins/genes contains known and putative/probable catalases, peroxidases, SODs, peroxiredoxins, glutaredoxins, 
thioredoxins etc. collected from Aspergillus Genome Database (http://aspergillusgenome.org/).

(2) TCA cycle. This group contains all the proteins/ genes related to the mentioned biochemical pathways according to Flipphi et al. [55].

(3) Iron transport. This gene group was created according to Haas [16] and to the Aspergillus Genome Database using the related GO terms and their child terms.

(4) Squalene - ergosterol pathway. The gene group was generated according to Alcazar-Fuoli and Mellado [56]. This pathway does not contain the first steps of sterol biosynthesis that are shared with other pathways, e.g. with siderophore biosynthesis.

(5) Heme binding. This group contains the proteins/ genes belonging to the "Heme binding" FunCat term according to FungiFun2 webpage [53].

(6) Respiration,

(7) $\mathrm{Cu}^{2+}$ transport,

(8) $\mathrm{Zn}^{2+}$ transport,

(9) Fe-S cluster assembly,

(10) Heme biosynthesis",

(11) Drug transmembrane transport,

(12) Iron-sulfur cluster binding and

(13) Transcription factors. These groups of proteins/ genes were constructed based on the Aspergillus Genome Database using the related GO terms and their child terms. Genes/proteins presented in the "TCA cycle" group were omitted from the "Respiration" group.
(14) Secondary metabolite cluster genes/proteins were collected according to Inglis et al. [57] and Lin et al. [58]. Only genes of clusters determined either manually or experimentally were involved in the analysis. Key genes were defined as secondary metabolite cluster genes encoding transcription factors (TFs), non-ribosomal peptide synthases (NRPSs), polyketide synthases (PKSs), or dimethylallyl tryptophan synthases (DATS). A secondary metabolite biosynthetic gene cluster was considered as up- or down-regulated if the up- or down-regulated genes within the cluster were significantly $(p<0.05)$ enriched in the studied gene set according to the Fisher's exact test.

\section{Results}

\section{Comparison of transcriptomic and proteomic data}

In order to test how iron deprivation modifies the oxidative stress response of $A$. fumigatus, the transcriptome (Fig. 1, Table 1) and proteome of four different cultures, - $\mathrm{Fe} /-\mathrm{H}_{2} \mathrm{O}_{2}$ (iron-deprived), $\left.+\mathrm{Fe} /+\mathrm{H}_{2} \mathrm{O}_{2}\right)\left(\mathrm{H}_{2} \mathrm{O}_{2}\right.$-treated), - $\mathrm{Fe} /+\mathrm{H}_{2} \mathrm{O}_{2}$ (iron-deprived- $\mathrm{H}_{2} \mathrm{O}_{2}$-treated), and $+\mathrm{Fe} /-$ $\mathrm{H}_{2} \mathrm{O}_{2}$ (iron-replete) cultures were studied in three biological replicates. The $-\mathrm{Fe} /-\mathrm{H}_{2} \mathrm{O}_{2}$ and the $-\mathrm{Fe} /+\mathrm{H}_{2} \mathrm{O}_{2}$ conditions resulted in significant changes at both the transcriptome and the proteome level in comparison to $+\mathrm{Fe} /-\mathrm{H}_{2} \mathrm{O}_{2}$ control cultures (Fig. 2, Tables 2 and 3).

In contrast, the $\mathrm{H}_{2} \mathrm{O}_{2}$-induced oxidative stress had only a moderate effect on both the transcriptome and the proteome of $A$. fumigatus cultures cultivated under

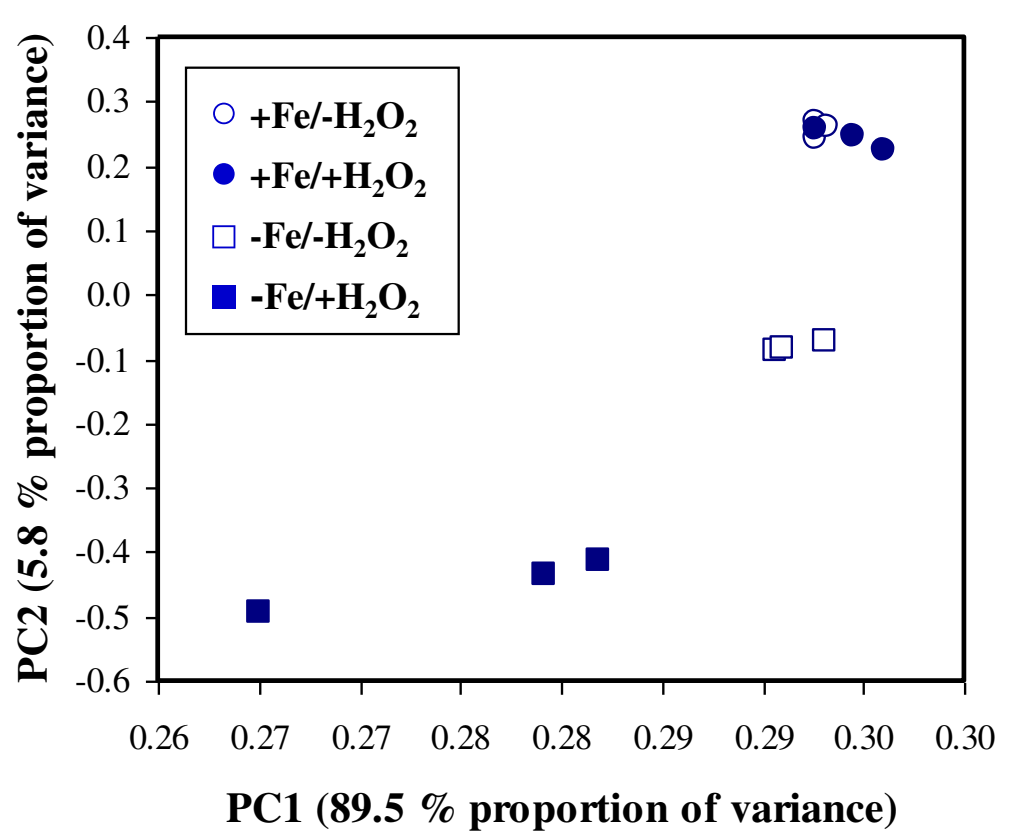

Fig. 1 Principal component analysis of the transcriptome data. Symbols represent $+\mathrm{Fe} /-\mathrm{H}_{2} \mathrm{O}_{2}(\mathrm{O}),+\mathrm{Fe} /+\mathrm{H}_{2} \mathrm{O}_{2}(\bullet),-\mathrm{Fe} /-\mathrm{H}_{2} \mathrm{O}_{2}(\square)$ and $-\mathrm{Fe} /+\mathrm{H}_{2} \mathrm{O}_{2}$ (a) cultures 
Table 1 Basic statistics of the transcriptome data

\begin{tabular}{llll}
\hline Sample & $\begin{array}{l}\text { Total } \\
\text { reads }\left(10^{6}\right)\end{array}$ & $\begin{array}{l}\text { Mapped } \\
\text { reads }\left(10^{6}\right)\end{array}$ & $\begin{array}{l}\text { Mapped } \\
\text { ratio }(\%)\end{array}$ \\
\hline$+\mathrm{Fe} /-\mathrm{H}_{2} \mathrm{O}_{2} 1$ & 19.0 & 18.3 & 96.0 \\
$+\mathrm{Fe} /-\mathrm{H}_{2} \mathrm{O}_{2} 2$ & 15.3 & 14.7 & 95.5 \\
$+\mathrm{Fe} /-\mathrm{H}_{2} \mathrm{O}_{2} 3$ & 14.8 & 14.2 & 96.0 \\
Sum: & 49.2 & 47.2 & 95.9 \\
$+\mathrm{Fe} /+\mathrm{H}_{2} \mathrm{O}_{2} 1$ & 18.8 & 17.9 & 95.5 \\
$+\mathrm{Fe} /+\mathrm{H}_{2} \mathrm{O}_{2} 2$ & 17.1 & 16.3 & 95.7 \\
$+\mathrm{Fe} /+\mathrm{H}_{2} \mathrm{O}_{2} 3$ & 14.6 & 14.0 & 95.8 \\
Sum: & 50.5 & 48.3 & 95.7 \\
$-\mathrm{Fe} /-\mathrm{H}_{2} \mathrm{O}_{2} 1$ & 15.0 & 14.4 & 95.9 \\
$-\mathrm{Fe} /-\mathrm{H}_{2} \mathrm{O}_{2} 2$ & 16.3 & 15.6 & 95.5 \\
$-\mathrm{Fe} /-\mathrm{H}_{2} \mathrm{O}_{2} 3$ & 17.6 & 16.8 & 95.6 \\
Sum: & 48.9 & 46.8 & 95.7 \\
$-\mathrm{Fe} /+\mathrm{H}_{2} \mathrm{O}_{2} 1$ & 16.4 & 15.8 & 95.8 \\
$-\mathrm{Fe} /+\mathrm{H}_{2} \mathrm{O}_{2} 2$ & 18.3 & 17.6 & 96.0 \\
$-\mathrm{Fe} /+\mathrm{H}_{2} \mathrm{O}_{2} 3$ & 16.1 & 15.5 & 96.1 \\
Sum: & 50.9 & 48.9 & 96.0 \\
Total sum: & 199.5 & 191.1 & 95.8 \\
\hline
\end{tabular}

iron-replete conditions (Fig. 2, Tables 2 and 3). It cannot be ruled out that the applied $3 \mathrm{mM}$ concentration of $\mathrm{H}_{2} \mathrm{O}_{2}$ was not sufficient to elicit more significant transcriptomic and proteomics changes. However, higher $\mathrm{H}_{2} \mathrm{O}_{2}$ concentrations were lethal under iron-deprived conditions (data not shown) and, in addition, even a $\mathrm{H}_{2} \mathrm{O}_{2}$ concentration of $2 \mathrm{mM}$ was shown to activate an AfYap1-dependent oxidative stress response in $A$. fumigatus [36]. The recorded changes at the mRNA and protein level showed a relatively good correlation for the comparison of cultures grown under $-\mathrm{Fe} /-\mathrm{H}_{2} \mathrm{O}_{2}$ vs. - $\mathrm{Fe} /$
$+\mathrm{H}_{2} \mathrm{O}_{2}$ conditions (Fig. 3). Nevertheless, a weaker correlation of the transcriptome and proteome data was found for the $+\mathrm{Fe} /+\mathrm{H}_{2} \mathrm{O}_{2}$ vs. $+\mathrm{Fe} /-\mathrm{H}_{2} \mathrm{O}_{2}$ and the $-\mathrm{Fe} /+\mathrm{H}_{2} \mathrm{O}_{2}$ vs. $-\mathrm{Fe} /-\mathrm{H}_{2} \mathrm{O}_{2}$ cultures (Fig. 3 ).

\section{Characterization of the stress responsive genes/proteins}

To understand the physiological changes under the applied stress conditions, the stress responsive genes/proteins were studied by enrichment analysis using FunCat, GO, and KEGG pathway terms (Additional file 2, Tables 2 and 3). The regulations of the following gene/ protein groups, which are potentially important for the oxidative stress or iron starvation response and/or the virulence of $A$. fumigatus [6-10], were also studied in detail: (1) "Antioxidant enzymes"; (2) genes/proteins related to iron metabolism including "Iron transport", "Fe-S cluster assembly", "Heme biosynthesis", "Fe-S cluster binding", "Heme binding", "TCA cycle", "Respiration", "Squalene-ergosterol pathway"; (3) further genes/proteins related to the virulence including "Cu-transport", "Zntransport", "Drug transmembrane transport" and "Secondary metabolite cluster genes"; as well as (4) "Transcription factors" (Additional files 3 and 4). For selected genes, the transcriptional changes were also confirmed by RT-qPCR (Additional file 5).

\section{Effects of iron deprivation (-Fe/- $\mathrm{H}_{2} \mathrm{O}_{2}$ vs. $+\mathrm{Fe} /-\mathrm{H}_{2} \mathrm{O}_{2}$ )}

Enrichment analyses of stress responsive genes and proteins under iron-deprived conditions suggested upregulation of siderophore metabolism, alterations in secondary metabolism and amino acid metabolism, as well as down-regulation of translation, formation of heme and FeS cluster proteins, TCA cycle and mitochondrial respiration (Additional files 2, 3, 4 and 5, Tables 2 and 3).

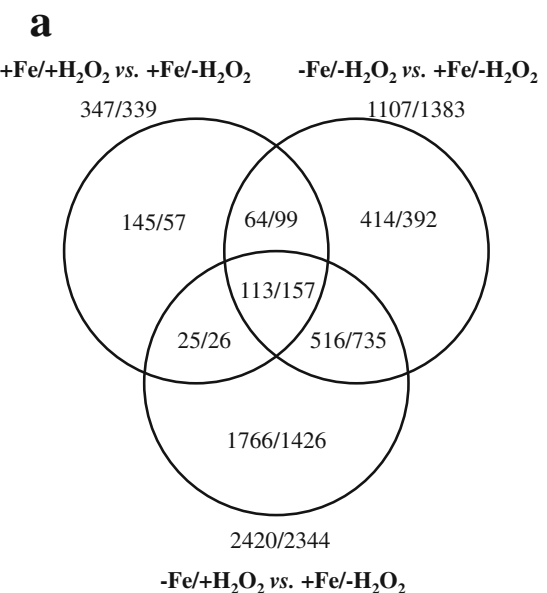

\section{b}

$+\mathrm{Fe} /+\mathrm{H}_{2} \mathrm{O}_{2}$ vs. $+\mathrm{Fe} /-\mathrm{H}_{2} \mathrm{O}_{2} \quad-\mathrm{Fe} /-\mathrm{H}_{2} \mathrm{O}_{2}$ vs. $+\mathrm{Fe} /-\mathrm{H}_{2} \mathrm{O}_{2}$

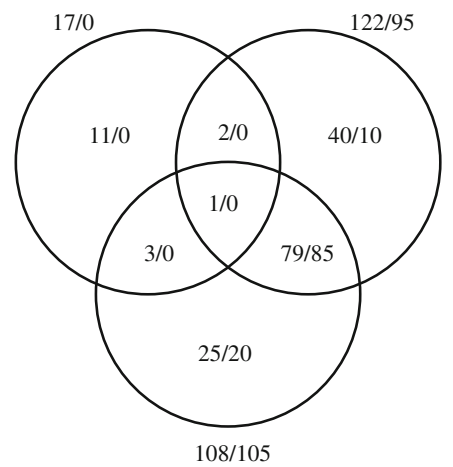

$-\mathrm{Fe} /+\mathrm{H}_{2} \mathrm{O}_{2}$ vs. $+\mathrm{Fe} /-\mathrm{H}_{2} \mathrm{O}_{2}$

Fig. 2 Venn-diagrams of the detected changes in the transcriptome and proteome. Graphs indicating the number of up-regulated/down-regulated (a) genes and (b) proteins 


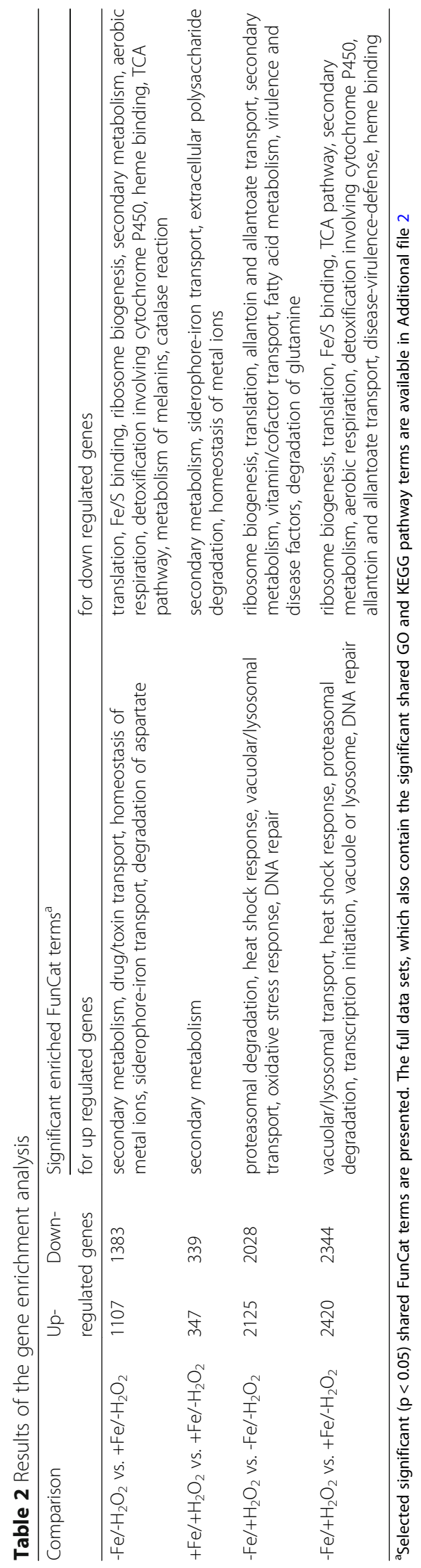




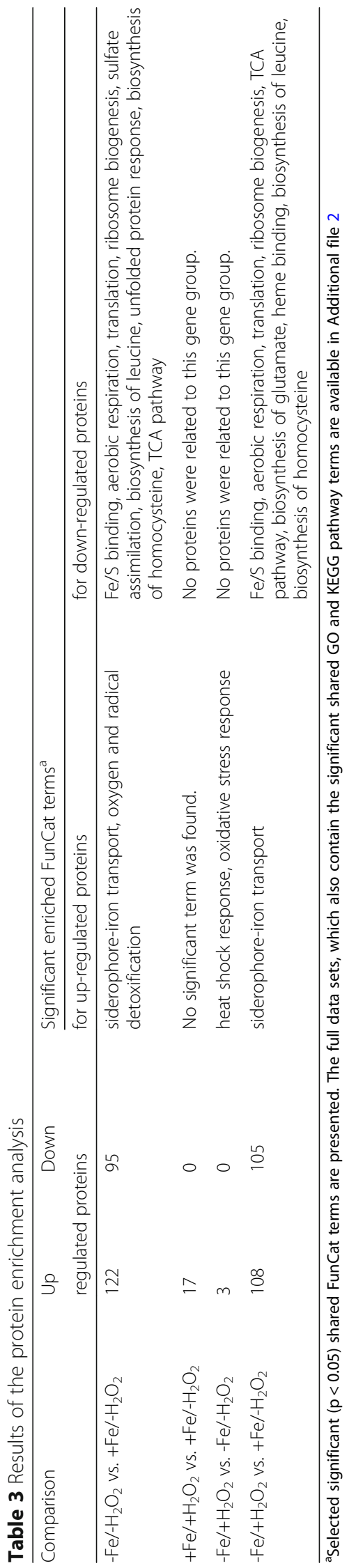




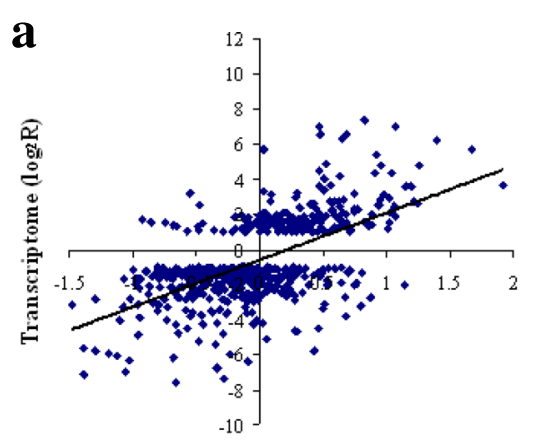

Proteome $\left(\log _{2} \mathrm{R}\right)$

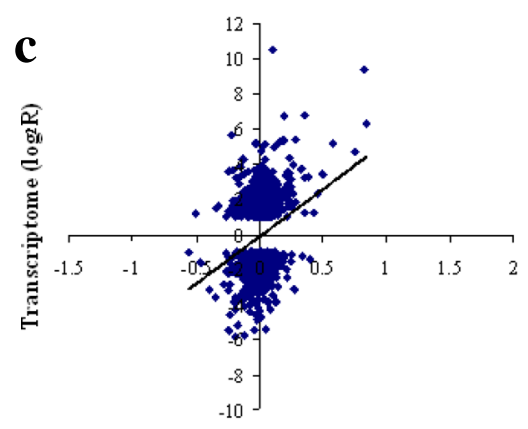

Proteome $\left(\log _{2} R\right)$

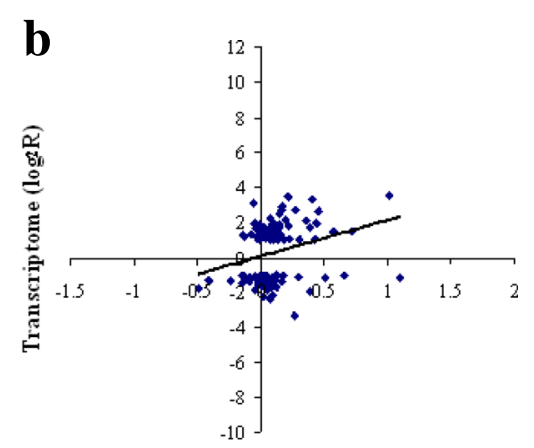

Proteome $\left(\log _{2} R\right)$

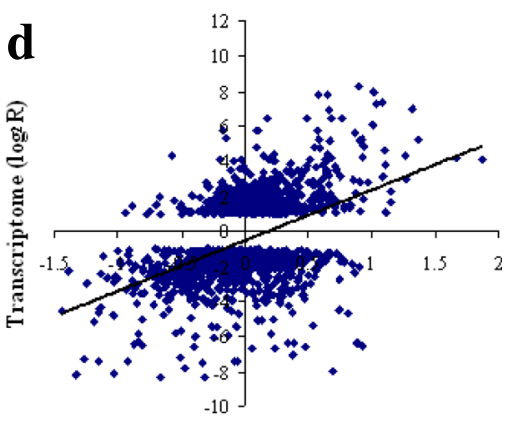

Proteome $\left(\log _{2} R\right)$

e

\begin{tabular}{llll}
\hline Experiment & $\rho^{\mathrm{a}}$ & $\rho^{\mathrm{b}}$ & $\rho^{\mathrm{c}}$ \\
\hline$-\mathrm{Fe} /-\mathrm{H}_{2} \mathrm{O}_{2}$ vs. $+\mathrm{Fe} /-\mathrm{H}_{2} \mathrm{O}_{2}$ & $0.39(\mathrm{p}<0.05)$ & $0.52(\mathrm{p}<0.05)$ & $0.68(\mathrm{p}<0.05)$ \\
$+\mathrm{Fe} /+\mathrm{H}_{2} \mathrm{O}_{2}$ vs. $+\mathrm{Fe} /-\mathrm{H}_{2} \mathrm{O}_{2}$ & $0.15(\mathrm{p}<0.05)$ & $0.36(\mathrm{p}<0.05)$ & $-0.03(\mathrm{p}=0.89)$ \\
$-\mathrm{Fe} /+\mathrm{H}_{2} \mathrm{O}_{2}$ vs. $-\mathrm{Fe} /-\mathrm{H}_{2} \mathrm{O}_{2}$ & $0.13(\mathrm{p}<0.05)$ & $0.21(\mathrm{p}<0.05)$ & n.c. \\
$-\mathrm{Fe} /+\mathrm{H}_{2} \mathrm{O}_{2}$ vs. $+\mathrm{Fe} /-\mathrm{H}_{2} \mathrm{O}_{2}$ & $0.32(\mathrm{p}<0.05)$ & $0.42(\mathrm{p}<0.05)$ & $0.66(\mathrm{p}<0.05)$ \\
\hline
\end{tabular}

Fig. 3 Correlation between proteome and transcriptome data. Data pairs containing the $\log _{2}$ ratio $\left(\log _{2} F C\right.$ ) of the mean FPKM values (in case of the up- or down regulated genes only) and the $\log _{2}$ ratio $\left(\log _{2} \mathrm{FC}\right)$ of the appropriate mean protein abundance values are presented. A - - $\mathrm{Fe} /-$ $\mathrm{H}_{2} \mathrm{O}_{2}$ vs. $+\mathrm{Fe} /-\mathrm{H}_{2} \mathrm{O}_{2} \mathrm{~B}-+\mathrm{Fe} /+\mathrm{H}_{2} \mathrm{O}_{2}$ vs. $+\mathrm{Fe} /-\mathrm{H}_{2} \mathrm{O}_{2}$. C - - Fe/ $+\mathrm{H}_{2} \mathrm{O}_{2}$ vs. $-\mathrm{Fe} /-\mathrm{H}_{2} \mathrm{O}_{2}$. D - - $\mathrm{Fe} /+\mathrm{H}_{2} \mathrm{O}_{2}$ vs. $+\mathrm{Fe} /-\mathrm{H}_{2} \mathrm{O}_{2}$. E - Pairwise Spearman's rank correlation coefficients calculated from the $\log _{2} \mathrm{FC}$ values (transcriptome vs. proteome). a - all available transcriptome vs. proteome data pairs. b - transcriptome data of up- or down-regulated genes only vs. proteome data. c - proteome data of up- or down-regulated proteins only vs. transcriptome data. n.c. - We found only three up- or down-regulated proteins, therefore a correlation coefficient was not calculated in this case

Iron deprivation caused alterations in the antioxidant defense system of $A$. fumigatus. Down-regulation of the iron-containing enzymes Cat1 and Ccp1 (peroxidase) were detected on the transcriptome and proteome level, while certain iron-free antioxidant enzymes i.e. Trr1 (putative thioredoxin reductase), Afu5g11320 (putative thioredoxin), and Sod1 (CuZn-SOD) were up-regulated (Additional files 3 and 5). Iron deprivation also induced alterations in the redox status of $A$. fumigatus as visualized by the ROS-activated fluorescent probe $2^{\prime}, 7^{\prime}$ dichlorofluorescein diacetate (Fig. 4).

Up-regulation of siderophore metabolism (siderophore biosynthesis and ferri-siderophore uptake) was accompanied by the up-regulation of amcA and $h m g 2$, which are both involved in supplying precursors for siderophore biosynthesis (Additional file 3). The amcA gene encodes a transporter involved in the mitochondrial export of L-ornithine [59], which is the main precursor of siderophore biosynthesis in A. fumigatus. The gene hmg2 encodes the enzyme hydroxymethylglutaryl-CoA reductase, which catalyzes the formation of mevalonate, a precursor of the extracellular siderophores fusarinine $\mathrm{C}$ and triacetyl-fusarinine $\mathrm{C}$ (TAF-C) [60]. Moreover, synchronous up-regulation of the iron regulator hapX [35] and down-regulation of the GATA-factor sreA (a repressor of siderophore biosynthesis [61, 62]) were also observed (Additional files 3 and 5). Elevated siderophore 


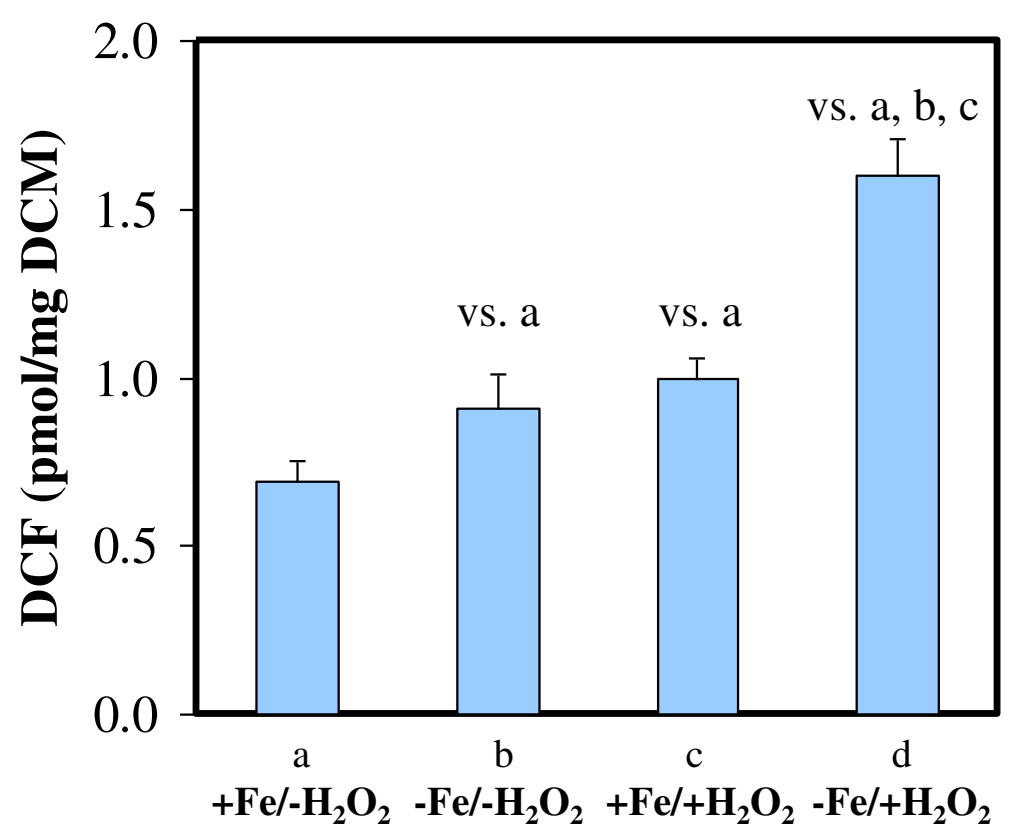

Fig. 4 DCF production of the $-\mathrm{Fe} /+\mathrm{H}_{2} \mathrm{O}_{2}$ A. fumigatus cultures. Redox imbalance caused by stress treatment was quantified with the 2',7'dichlorofluorescin diacetate assay. DCF productions were given as produced pmol DCF / mg dry cell mass (DCM). Mean \pm S.D. calculated from three independent experiments are presented. The label "vs. a", "vs. b", and "vs. C" represent significantly increased DCF production compared to iron-repleted $(+\mathrm{Fe})$, iron-depleted $(-\mathrm{Fe})$, and $\mathrm{H}_{2} \mathrm{O}_{2}$-treated iron-replete $\left(+\mathrm{Fe} /+\mathrm{H}_{2} \mathrm{O}_{2}\right)$ cultures, respectively, according to Student's t-test $(p<0.05)$

production was also confirmed by the CAS assay; $49 \pm 6 \mu \mathrm{M}$ $(n=4)$ of extracellular siderophores $(50 \mathrm{~h})$ were detected in iron-starved cultures, while $<3 \mu \mathrm{M}$ was measured in ironreplete cultures.

It is notable that although several Fe-S cluster- and heme-binding proteins were down-regulated (Additional files 3 and 5) together with a few important genes of Fe-S cluster assembly (e.g. isa1 [35]) and heme biosynthesis (e.g. hemA [35]), no bulk downregulation of genes belonging to these processes was observed (Additional file 3). Moreover, up-regulation of genes encoding iron-dependent ergosterol biosynthesis enzymes (erg3A, erg3B, erg25A, erg25B) (Additional files 3 ) and corresponding increased levels of the enzyme Erg3A was detected (Additional file 3). In contrast, we could not identify the up-regulation of any other iron-dependent, ergosterol biosynthetic enzymes, including Erg5 (sterol C22 desaturase), Cyp51A and B (lanosterol 14 $\alpha$-demethylases), or their corresponding genes (Additional file 3).

Up-regulation of drug transmembrane transport genes as well as the down-regulation of $\mathrm{Zn}^{2+}$ and $\mathrm{Cu}^{2+}$ transport genes was also observed (Additional file 3). When one considers the stress-dependent expression of secondary metabolite biosynthetic genes, both up- and down-regulated genes that fall into this category were significantly enriched under iron deprivation (Additional files 4 and 5). Five secondary metabolite biosynthetic gene clusters (fumagillin, siderophore, hexadehydro-astechrome, pseurotin A, and Afu3g02670 clusters) showed significant up-regulation, while ten clusters (DHN-melanin, endocrocin, fumigaclavine C, fumipyrrole, fumiquinazoline, fumitremorgin B, gliotoxin, Afu3g13730, and Afu6g13930 clusters together with the "No PKS or NRPS backbone 6" cluster) showed significant downregulation (Table 4).

\section{Effect of $\mathrm{H}_{2} \mathrm{O}_{2}$ treatment on iron-replete cultures ( $+\mathrm{Fe} /+\mathrm{H}_{2} \mathrm{O}_{2}$ vs. $+\mathrm{Fe} /-\mathrm{H}_{2} \mathrm{O}_{2}$ cultures)}

The employed oxidative stress treatment caused significant alterations in the redox homeostasis of iron-replete hyphae (Fig. 4). However, functional analysis of up- and down-regulated genes resulted in few significant shared FunCat, GO, or KEGG pathway terms, which reflected changes in secondary metabolism and also indicated down-regulation of siderophore biosynthesis (Table 2, Additional file 2) and $\mathrm{Cu}^{2+}$ transport (Additional file 3). At the level of proteome, only the GO terms "hydrogen peroxide catabolic process" and "removal of superoxide radicals" were significantly enriched. However, these two biological processes incorporated only two proteins: the putative thioredoxin reductase Trr1 and the catalase Cat2 (Additional files 2 and 3).

Similar to iron-deprived conditions, both up- and downregulated genes involved in the biosynthesis of secondary metabolites were significantly enriched (Additional file 4): Seven gene clusters (endocrocin, 
Table 4 Regulation of selected secondary metabolism biosynthetic gene clusters

\begin{tabular}{|c|c|c|c|c|c|}
\hline \multirow[t]{2}{*}{ Cluster } & \multirow{2}{*}{$\begin{array}{l}\text { Cluster } \\
\text { size }^{a}\end{array}$} & \multicolumn{4}{|c|}{ Related genes (up-regulated/down-regulated) } \\
\hline & & $\begin{array}{l}-\mathrm{Fe} /-\mathrm{H}_{2} \mathrm{O}_{2} \text { vs. }+\mathrm{Fe} /- \\
\mathrm{H}_{2} \mathrm{O}_{2}\end{array}$ & $\begin{array}{l}+\mathrm{Fe} /+\mathrm{H}_{2} \mathrm{O}_{2} \text { vs. }+\mathrm{Fe} /- \\
\mathrm{H}_{2} \mathrm{O}_{2}\end{array}$ & $\begin{array}{l}-\mathrm{Fe} /+\mathrm{H}_{2} \mathrm{O}_{2} \text { vs. - } \mathrm{Fe} /- \\
\mathrm{H}_{2} \mathrm{O}_{2}\end{array}$ & $\begin{array}{l}-\mathrm{Fe} /+\mathrm{H}_{2} \mathrm{O}_{2} \text { vs. }+\mathrm{Fe} /- \\
\mathrm{H}_{2} \mathrm{O}_{2}\end{array}$ \\
\hline DHN-melanin cluster & 10 & $1 / 8^{\mathrm{b}}$ & $1 / 0$ & $3 / 0$ & $2 / 7^{\mathrm{b}}$ \\
\hline Endocrocin cluster & 9 & $2 / 4^{b}$ & $5^{\mathrm{b}} / 1$ & $1 / 4$ & $1 / 5^{\mathrm{b}}$ \\
\hline Fumagillin cluster & 15 & $8^{\mathrm{b}} / 0$ & $11^{\mathrm{b}} / 0$ & $0 / 15^{\mathrm{b}}$ & $1 / 2$ \\
\hline Fumigaclavine C (fga) cluster & 11 & $0 / 5^{b}$ & $4^{\mathrm{b}} / 0$ & $0 / 1$ & $0 / 6^{b}$ \\
\hline Fumipyrrole cluster & 7 & $0 / 7^{b}$ & $0 / 0$ & $2 / 1$ & $1 / 7^{\mathrm{b}}$ \\
\hline Fumiquinazoline cluster & 5 & $0 / 5^{b}$ & $1 / 0$ & $1 / 0$ & $0 / 4^{b}$ \\
\hline Fumitremorgin B (ftm) cluster & 9 & $0 / 4^{b}$ & $0 / 0$ & $0 / 7^{b}$ & $0 / 8^{b}$ \\
\hline Siderophore cluster & 18 & $10^{\mathrm{b}} / 5$ & $0 / 10^{\mathrm{b}}$ & $9^{b} / 3$ & $11^{b} / 3$ \\
\hline Gliotoxin (gli) cluster & 12 & $0 / 12^{b}$ & $2 / 0$ & $4 / 1$ & $0 / 12^{b}$ \\
\hline Hexadehydro-astechrome cluster & 8 & $7^{\mathrm{b}} / 0$ & $5^{\mathrm{b}} / 0$ & $1 / 4$ & $3 / 0$ \\
\hline Pseurotin A cluster & 4 & $3^{\mathrm{b}} / 0$ & $4^{\mathrm{b}} / 0$ & $0 / 4^{b}$ & $0 / 1$ \\
\hline Afu1g01010 cluster & 4 & $2 / 0$ & $1 / 0$ & $0 / 4^{b}$ & $0 / 1$ \\
\hline Afu3g01410 cluster & 9 & $2 / 0$ & $2^{\mathrm{b}} / 0$ & $3 / 4$ & $2 / 3$ \\
\hline $\begin{array}{l}\text { Afu3g02570 and Afu3g02530 } \\
\text { clusters }\end{array}$ & 15 & $4 / 3$ & $0 / 2$ & $7^{\mathrm{b}} / 0$ & $6 / 2$ \\
\hline Afu3g02670 cluster & 7 & $3^{\mathrm{b}} / 0$ & $0 / 1$ & $1 / 2$ & $3 / 0$ \\
\hline Afu3g13730 cluster & 9 & $0 / 5^{b}$ & $0 / 4^{b}$ & $0 / 1$ & $0 / 5^{\mathrm{b}}$ \\
\hline Afu5g10120 cluster & 10 & $3 / 0$ & $1 / 0$ & $2 / 0$ & $6 \% / 0$ \\
\hline Afu6g13930 cluster & 9 & $0 / 9^{b}$ & $0 / 2^{b}$ & $1 / 5^{b}$ & $0 / 9^{b}$ \\
\hline Afu7g00170 cluster & 7 & $1 / 1$ & $4^{\mathrm{b}} / 0$ & $1 / 0$ & $1 / 0$ \\
\hline No PKS or NRPS backbone 6 cluster & 13 & $1 / 5^{b}$ & $0 / 2$ & $3 / 1$ & $3 / 5$ \\
\hline Number of up-regulated clusters & & 5 & 7 & 2 & 2 \\
\hline Number of down-regulated clusters & & 10 & 3 & 5 & 9 \\
\hline
\end{tabular}

${ }^{a}$ Number of genes belonging to the cluster. The full data sets are available in Additional file 4

${ }^{b}$ Significantly enriched gene group according to the Fisher's exact test $(p<0.05)$

fumagillin, fumigaclavine $\mathrm{C}$, hexadehydro-astechrome, pseurotin A, Afu3g01410, and the dimethylallyl tryptophan synthase containing Afu7g00170 cluster) showed significant up-regulation, meanwhile only three clusters (siderophore, Afu3g13730, and Afu6g13930) showed concomitant downregulation (Table 4, Additional files 4 and 5).

\section{Combined effects of iron-deprivation and $\mathrm{H}_{2} \mathrm{O}_{2}$ treatment on control cultures (-Fe/ $+\mathrm{H}_{2} \mathrm{O}_{2}$ vs. $+\mathrm{Fe} /-\mathrm{H}_{2} \mathrm{O}_{2}$ )}

$\mathrm{H}_{2} \mathrm{O}_{2}$-treatment of iron-deprived cultures perturbed significantly the redox homeostasis of hyphae (Fig. 4) and, concomitantly, induced the expression of a group of DNA repair, heat shock and oxidative stress response genes, which coincided with the induction of atfA, yap1, and $h s f 1$ genes (Table 2, Additional files 2 and 3) coding for important transcription factors governing oxidative and heat stress responses in $A$. fumigatus [21, 25, 36, 63]. Macroautophagy, ubiquitin-dependent protein degradation (Additional file 2), as well as siderophore metabolism and drug transmembrane transport were also induced, meanwhile the down-regulations of genes involved in translation, ribosome biogenesis, TCA cycle, the squalene-ergosterol biosynthesis pathway, respiration, and $\mathrm{Zn}^{2+}$ transport were detected (Table 2, Additional files 2 and 3).

Regarding secondary metabolism, the Afu5g10120 and siderophore clusters showed up-regulation, whereas nine clusters (DHN-melanin, endocrocin, fumigaclavine $\mathrm{C}$, fumipyrrole, fumiquinazoline, fumitremorgin B gliotoxin, Afu3g13730, and Afu6g13930 clusters) were downregulated (Table 4, Additional files 4 and 5).

Although the down-regulated genes encoding heme binding and Fe-S cluster binding proteins were significantly enriched under combined stress conditions, many other genes of this category (12 and 12 genes, respectively), together with 7 genes from the "Fe-S cluster assembly" group - showed up-regulation (Additional file 3). Importantly, these up-regulations were exclusively detected at the transcript level (Additional file 3). Only the 
Afu2g14960 gene, which encodes a putative Fe-S binding protein, showed a concomitant up-regulation on the protein level (Additional file 3).

\section{Effect of $\mathrm{H}_{2} \mathrm{O}_{2}$-induced oxidative stress on iron-deprived cultures $\left(-\mathrm{Fe} /+\mathrm{H}_{2} \mathrm{O}_{2}\right.$ vs. $\left.-\mathrm{Fe} /-\mathrm{H}_{2} \mathrm{O}_{2}\right)$}

To better understand the impact of $\mathrm{H}_{2} \mathrm{O}_{2}$ on irondeprived cultures, we directly compared the transcriptome and the proteome of $A$. fumigatus grown under $-\mathrm{Fe} /+\mathrm{H}_{2} \mathrm{O}_{2}$ and $-\mathrm{Fe} /-\mathrm{H}_{2} \mathrm{O}_{2}$ conditions $\left(-\mathrm{Fe} /+\mathrm{H}_{2} \mathrm{O}_{2}\right.$ vs. $-\mathrm{Fe} /-\mathrm{H}_{2} \mathrm{O}_{2}$ ). In addition, we addressed the question of whether the effect of $\mathrm{H}_{2} \mathrm{O}_{2}$ differs between iron-replete cultures $\left(+\mathrm{Fe} /+\mathrm{H}_{2} \mathrm{O}_{2}\right.$ vs. $\left.+\mathrm{Fe} /-\mathrm{H}_{2} \mathrm{O}_{2}\right)$ and iron-deprived cultures $\left(-\mathrm{Fe} /+\mathrm{H}_{2} \mathrm{O}_{2}\right.$ vs. $\left.-\mathrm{Fe} /-\mathrm{H}_{2} \mathrm{O}_{2}\right)$.

The changes detected in the functionally-related gene groups during the comparison of $-\mathrm{Fe} /+\mathrm{H}_{2} \mathrm{O}_{2}$ and $-\mathrm{Fe} /-\mathrm{H}_{2} \mathrm{O}_{2}$ cultures were generally similar to those found in the $-\mathrm{Fe} /$ $+\mathrm{H}_{2} \mathrm{O}_{2}$ vs. $+\mathrm{Fe} /-\mathrm{H}_{2} \mathrm{O}_{2}$ comparison (Tables 2,3 and 4, Additional files 2, 3 and 4). The major differences were as follows: neither iron transport genes nor $\mathrm{Zn}^{2+}$ transport genes showed further transcriptional changes in comparison to the iron-deprived cultures (Additional file 3). Surprisingly, the Fe-S cluster assembly genes showed clear up-regulation, meanwhile the drug transmembrane transport genes were down-regulated in comparison to $-\mathrm{Fe} /+\mathrm{H}_{2} \mathrm{O}_{2}$ and $-\mathrm{Fe} /-\mathrm{H}_{2} \mathrm{O}_{2}$ cultures (Additional files 3 and 5). The genes of Fe-S cluster binding proteins and genes involved in respiration were not down-regulated (Additional file 3). Moreover, many of them showed up-regulation. However, this group of genes was not significantly enriched (Additional file 3). The repression of several other "iron-dependent" genes during iron deprivation was also overruled, at least partially, by oxidative stress induction. Prominent examples are the aconitase-encoding gene aco $A$, the heme biosynthesis gene hem 13 and the catalase genes cat 1 and cat2 (Additional file 3).

Addition of $\mathrm{H}_{2} \mathrm{O}_{2}$ to iron-deprived cultures caused very significant transcriptional changes different from that found in iron-replete cultures (Tables 1 and 2, Fig. 1). Both the number and function of stress responsive genes were different (Table 2 ) and only $5.8 \%$ of stress responsive genes showed similar (unidirectional) transcriptional changes in both cultures challenged with $\mathrm{H}_{2} \mathrm{O}_{2}(+\mathrm{Fe} /$ $+\mathrm{H}_{2} \mathrm{O}_{2}$ vs. $+\mathrm{Fe} /-\mathrm{H}_{2} \mathrm{O}_{2}$ and $-\mathrm{Fe} /+\mathrm{H}_{2} \mathrm{O}_{2}$ vs. $\left.-\mathrm{Fe} /-\mathrm{H}_{2} \mathrm{O}_{2}\right)$ (Fig. 5). The regulation of genes coding for antioxidative enzymes illustrates nicely the dependence of the oxidative stress response on iron availability: in total 12 antioxidative enzyme genes showed down-regulation under iron deprivation. Five of them (cat2 and aspf 29 encoding a putative bifunctional catalase-peroxidase and a putative thioredoxin, respectively, Afu3g12270 and Afu3g12270 coding for putative glutathione peroxidases, and also the Afu5g15070 peroxiredoxin gene) were up-regulated under combined stresses. In contrast, $\mathrm{H}_{2} \mathrm{O}_{2}$-induced oxidative stress alone did not induce their expression (Additional

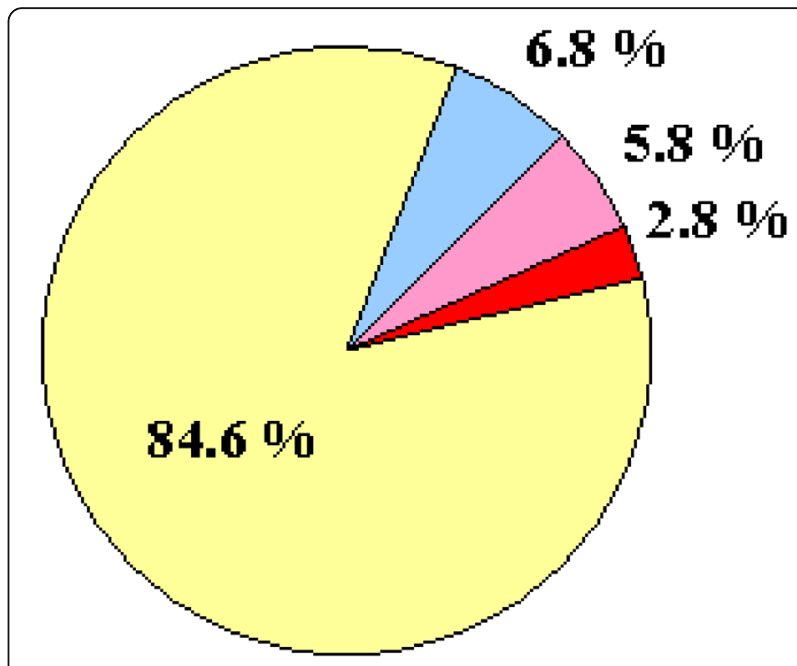

Fig. 5 Comparison of oxidative stress response in iron-replete $(+\mathrm{Fe} /$ $+\mathrm{H}_{2} \mathrm{O}_{2}$ vs. $\left.+\mathrm{Fe} /-\mathrm{H}_{2} \mathrm{O}_{2}\right)$ and iron-depleted cultures $\left(-\mathrm{Fe} /+\mathrm{H}_{2} \mathrm{O}_{2}\right.$ vs. $-\mathrm{Fe} /-\mathrm{H}_{2} \mathrm{O}_{2}$ ). Percentages of stress responsive genes (differentially expressed genes with at least two-fold transcriptional difference) detected only in iron-depleted cultures (yellow), only in iron-replete cultures (blue), in both cultures with unidirectional transcriptional changes (pink), and in both cultures with opposite transcriptional changes (red) are presented

file 3). In addition, a group of 11 genes was up-regulated under combined stress conditions; however, they were not stress responsive upon exposure to a single stress treatment (Additional file 3).

\section{Iron deprivation decreases the resistance to oxidative stress}

To investigate the link between iron supply and oxidative stress at the physiological level, we analyzed the growth response of $A$. fumigatus to oxidative stress in dependence on iron supply. As shown in Fig. 6a, iron deprivation in combination with the ferrous iron-specific chelator BPS, which inhibits reductive iron assimilation, significantly increased the susceptibility of $A$. fumigatus wild type to oxidative stress caused by the redox cyclers paraquat and menadione; i.e. radial growth of the wild-type strain was similar on $+\mathrm{Fe}$ and $-\mathrm{Fe} / \mathrm{BPS}$ media but the growth inhibition mediated by paraquat and menadione was significantly higher in -Fe/BPS compared to $+\mathrm{Fe}$ (e.g. $0.5 \mathrm{mM}$ paraquat and $0.01 \mathrm{mM}$ menadione had a negligible effect on + Fe medium but caused drastic growth reduction and growth inhibition, respectively, on -Fe/BPS medium). In agreement, the loss of siderophore-mediated iron uptake ( $\triangle$ sidA mutant) decreased resistance to these oxidative stress-causing reagents (Fig. 6b), e.g. on $+\mathrm{Fe}$ medium, $1 \mathrm{mM}$ and $2 \mathrm{mM} \mathrm{H}_{2} \mathrm{O}_{2}$ had minor effects on the wildtype strain but caused significant growth reduction and growth inhibition, respectively, of the $\triangle$ sidA mutant; similarly, on -Fe medium, $0.5 \mathrm{mM}$ paraquat had a negligible 


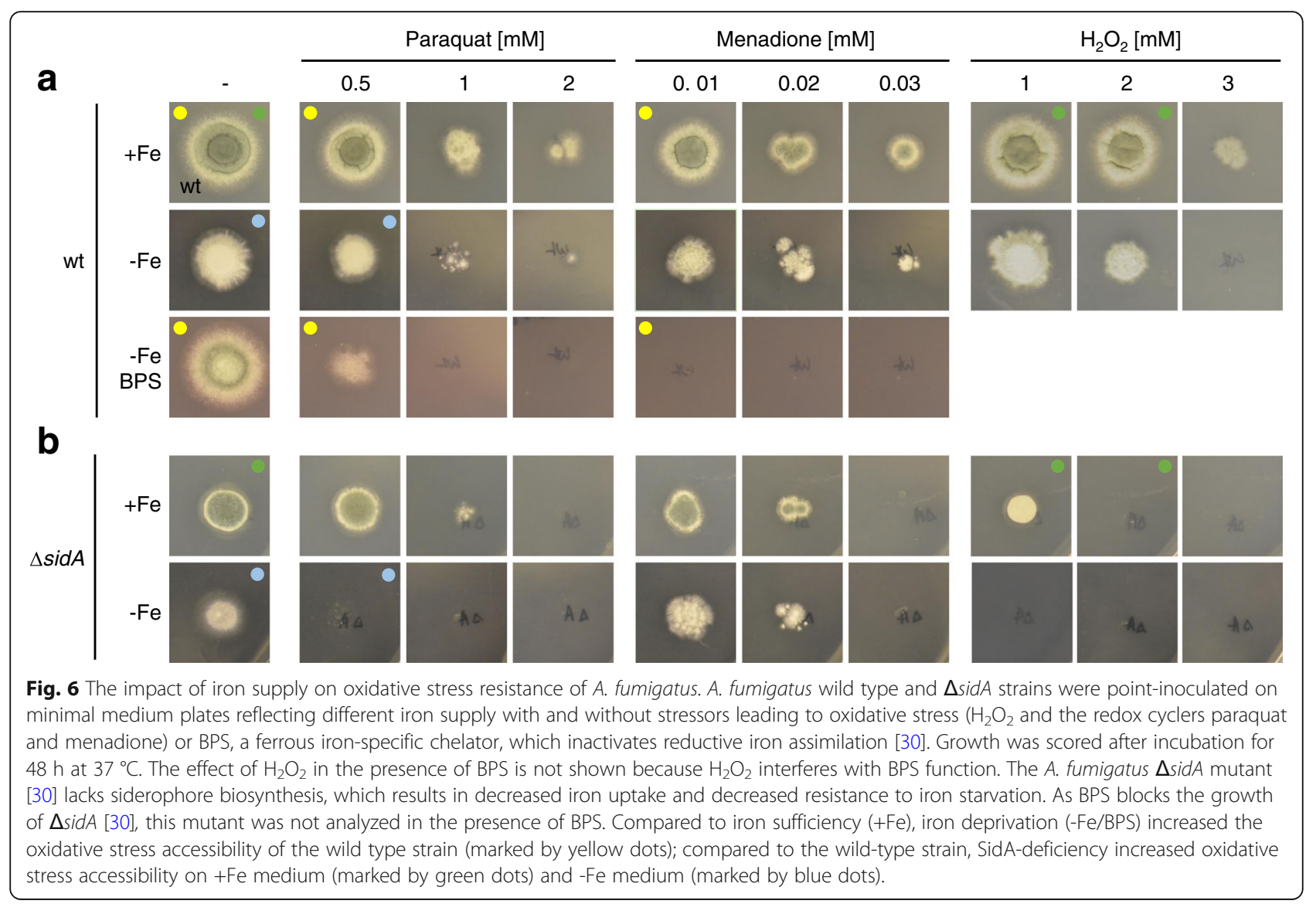

effect on the control strain but blocked growth of the $\triangle$ sidA mutant. Taken together, these data support our view - drawn from the transcriptome and proteome data - that iron deprivation aggravates oxidative stress.

\section{Discussion}

Iron is an essential transition metal nutrient for all living organisms including $A$. fumigatus. The accessibility of iron plays a crucial role during $A$. fumigatus infections $[16,59]$ and, not surprisingly, several elements of its iron metabolism have a determinative impact on the virulence of this fungus [30, 32-35]. However, during fungus-host interactions, $A$. fumigatus is exposed to combinatorial stress including confrontation with ROS. In this study, we demonstrated that the response to combinations of stresses (iron depletion plus oxidative stress) differs considerably to the response to a single stress (iron depletion or oxidative stress alone).

\section{Adaptation to iron-deprivation}

The secretion of soluble iron-chelating siderophores under iron depletion is a well-studied mechanism in fungi. The up-regulation of siderophore metabolism under iron deprivation was underlined by both transcriptome and proteome data (Tables 2 and 3, Additional file 3). This is in good accordance with the results of previous studies $[35,59,62,64]$. Interestingly, the up-regulation of RIA elements (FetC, FreB, FtrA; [30, 61]) was not as obvious as it was in the case of siderophore metabolic enzymes, transporters, and regulators (Additional files 3 and 5).

The up-regulation of iron uptake was accompanied by several processes in order to economize and prioritize iron utilization including:

i) Repression of several elements of the mitochondrial electron transport chain as well as down-regulation of elements of the TCA cycle, like the iron-containing aconitase and succinate dehydrogenase, were observed (Additional file 3), which is in line with previous observations made by Schrettl et al. [35]. Restriction of these mitochondrial pathways represents an important response to iron starvation because mitochondria are the major iron-containing organelle found in fungal cells [65].

ii) Ribosome biogenesis and translation were also repressed in good accordance with earlier results of Schrettl et al. [35], and it was accompanied with down-regulation of the iron-sulfur protein Rli1 (Tables 2 and 3; Additional files 2 and 3). In 
Saccharomyces cerevisiae, the biogenesis of cytosolic ribosomes requires Rli1 and, as a consequence, this process depends on both iron availability and Fe-S cluster assembly [66]. Our data suggest that the orthologue of baker's yeast Rli1 may link ribosome biogenesis and mitochondrial Fe-S cluster assembly in A. fumigatus as well.

iii) Altogether $21 \mathrm{Fe}-\mathrm{S}$ cluster and 22 heme-binding proteins were down-regulated (Additional files 3 and 5).

The down-regulation of iron-dependent antioxidant enzymes (e.g. Cat1, Ccp1) was likely counterbalanced by the up-regulation of the iron-free proteins Trr1 (putative thioredoxin reductase), Afu5g11320 (putative thioredoxin), and Sod1 (CuZn-SOD) (Additional file 3). Up-regulation of Sod1 is in good accordance with the earlier results of Oberegger et al. [67]. Importantly, Sod1 is likely to protect Fe-S cluster proteins from the deleterious effects of superoxide [67, 68]. As expected, iron deprivation perturbed the redox balance of cells (Fig. 4) because both catalase and peroxidase activities were reduced, while respiration was impaired.

Interestingly, certain iron-dependent processes, e.g. sterol biosynthesis (the squalene-ergosterol pathway), were even up-regulated (Additional file 3). Earlier studies demonstrated that iron starvation decreased the sterol content of cells [64], which was explained by two major reasons. First, mevalonate is an intermediate of both TAF-C and sterol biosynthesis $[59,60]$ and, as a consequence, intensified TAF-C production decreases the metabolic flux towards sterols. Second, iron is needed for sterol biosynthesis and, therefore, iron starvation decreases the abundance/activity of certain ergosterol biosynthesis enzymes [60]. To prevent dangerous decreases in the sterol content, fungal cells need to maintain a balance between TAF-C production and sterol biosynthesis, which may be achieved by the induction of the squalene-ergosterol pathway genes. The upregulation of the aforementioned ergosterol biosynthesis genes together with the observation that no bulk down regulation of Fe-S cluster assembly and heme biosynthesis genes was observed (Additional file 3) suggests that iron starvation does not cause down-regulation of all iron-dependent enzymes/pathways but rather leads to a reprogramming to ensure survival under limited iron supply by prioritization of iron use.

\section{Effect of oxidative stress on iron-deprived cultures}

The applied $\mathrm{H}_{2} \mathrm{O}_{2}$ treatments had only minor effect on iron-supplemented cultures (Tables 2 and 3, Additional files 2, 3 and 4). However, the very same exposures to $\mathrm{H}_{2} \mathrm{O}_{2}$-elicited oxidative stress were clearly more harmful in iron-deprived cultures: Under the combination of
$\mathrm{H}_{2} \mathrm{O}_{2}$ and iron-deprivation stresses, i) many more genes were induced or repressed than in iron-replete cultures (Table 2), ii) the bulk up-regulation of DNA repair, heat shock, and oxidative stress response genes was observed, which coincided with up-regulation of genes involved in macroautophagy and ubiquitin-dependent protein degradation (Additional file 2, Table 2), iii) DCF production as a marker of redox imbalance in $\mathrm{H}_{2} \mathrm{O}_{2}$-treated and iron-depleted cultures was significantly higher than that observed in $\mathrm{H}_{2} \mathrm{O}_{2}$-treated iron-replete cultures (Fig. 4), and iv) physiological experiments also demonstrated that iron deprivation can reduce oxidative stress tolerance (Fig. 6). In this regard, it is particularly interesting that, as an example, carbon starvation stress did not decrease but even increased oxidative stress tolerance in yeast [69]. Our data shed light on the severity of combined oxidative and iron-deprivation stress in A. fumigatus, which highly supports the view that the combination of withholding iron from pathogens and attacking them with ROS is a highly efficient and, therefore, quite widespread strategy to prevent infections in mammalian hosts $[16,42,43]$.

Under $-\mathrm{Fe} /+\mathrm{H}_{2} \mathrm{O}_{2}$ stress conditions, A. fumigatus set into operation the following stress response processes to avoid or at least mitigate the deleterious effects of such combinatorial stresses (Fig. 7):

i) Several elements of the glutathione-glutaredoxinthioredoxin systems were induced and SODs were up-regulated ("iron-independent antioxidant enzymes"), meanwhile DNA repair, heat shock response, macroautophagy, and ubiquitin-dependent protein degradation genes were activated to protect the cells against ROS and to repair the damage caused by ROS under iron-depleted culture conditions (Table 2, Additional file 3).

ii) No further increases in the transcription of siderophore metabolic genes were detected in comparison to $-\mathrm{Fe}$ vs. +Fe treatments (Additional file 3). However, iron-deprivation and oxidative stress together clearly up-regulated the expression of RIA genes (Additional files 3 and 5).

iii) The production of iron-containing proteins followed interesting regulatory patterns. While iron deprivation down-regulated a significant group of "Fe-S cluster binding" and "Heme-binding" protein genes (21 and 22 genes, respectively), $\mathrm{H}_{2} \mathrm{O}_{2}$ treatment induced several genes in the same group (11 and 12 genes, respectively) under iron deprivation conditions (Additional file 3). Importantly, these changes were observed at the level of the transcriptome but not the proteome in almost all cases (Additional file 3). This may 


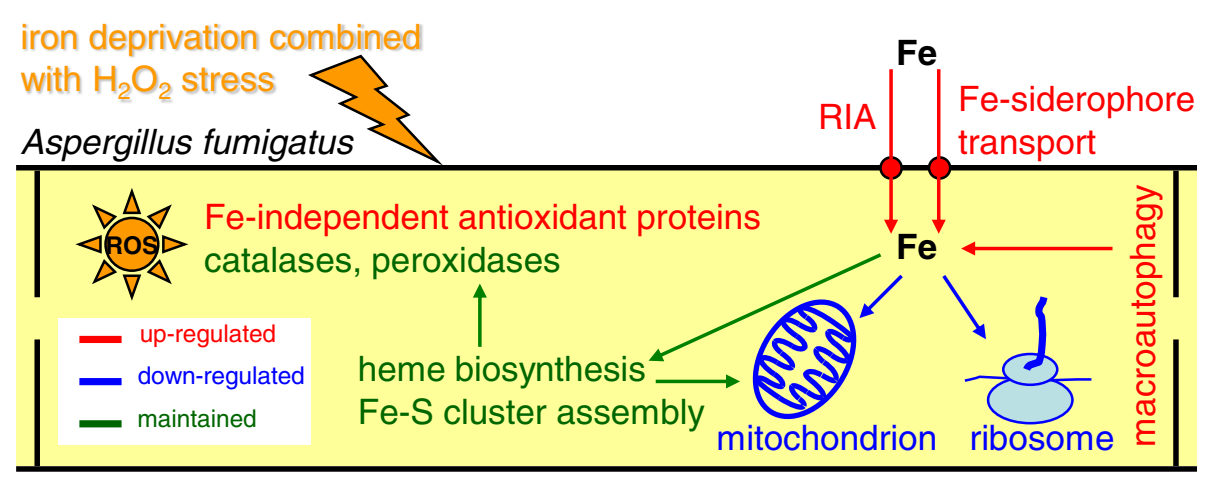

Fig. 7 Simplified model of adaptation mechanism to $\mathrm{H}_{2} \mathrm{O}_{2}$ stress under iron starvation in A. fumigatus based on the obtained proteomics and transcriptomics data

imply that the up-regulation of these genes is unable to increase the protein levels in the absence of sufficient amount of iron, at least during short-term response. However, preventing any further decrease in their quantities is also a favorable outcome of the up-regulation. Since ROS can inactivate Fe-S clusters [70], the upregulation of the related genes may also indicate the effort made by the fungus to repair this defect. The successful maintenance of ironcontaining protein pools can be an important or even one of the key elements of a successful long-term adaptation to iron starvation. Because the availability of iron is limited under these circumstances fungal cells may also use intracellular iron released by macroautophagy or ubiquitindependent protein degradation in addition to iron normally taken up via the siderophoremediated or RIA systems. In this respect, iron starvation resembles carbon starvation, under which cells release several carbohydrate-active enzymes (CAZymes) to obtain nutrients from their environment and also activate macroautophagy as well as cell wall degrading enzymes to re-utilize the cells' own building materials [71, 72]. Importantly, using a $\Delta a \operatorname{tg} 1$ mutant, which was impaired in autophagy, Richie et al. [73] clearly demonstrated that autophagy contributed to the recycling of metal ions including iron to maintain vegetative growth under nutrient limitations.

iv) No clear repression of the squalene-ergosterol pathway was observed under combined stresses. Although down-regulated genes (10 genes) were significantly enriched under these conditions in comparison to iron-replete cultures, other genes (8 genes) showed up-regulation in this pathway (Additional files 3). These observations suggest the essentiality of low concentrations of sterols even under $-\mathrm{Fe} /+\mathrm{H}_{2} \mathrm{O}_{2}$ stress. v) Ribosome biogenesis and translation genes were repressed further when compared to $-\mathrm{Fe} /-\mathrm{H}_{2} \mathrm{O}_{2}$ vs. $+\mathrm{Fe} /-\mathrm{H}_{2} \mathrm{O}_{2}$ treatment (Table 2). We assume that the reduced growth observed under combined stresses led to a decrease in the iron requirement of the cells and shifted the cells' energy production and assimilatory pathways towards the protection against oxidative stress.

The stress response observed in cultures exposed to iron-starvation $/ \mathrm{H}_{2} \mathrm{O}_{2}$ stress $\left(-\mathrm{Fe} /+\mathrm{H}_{2} \mathrm{O}_{2}\right.$ vs. $\left.+\mathrm{Fe} /-\mathrm{H}_{2} \mathrm{O}_{2}\right)$ was not a simple combination of iron deprivation (-Fe/$\mathrm{H}_{2} \mathrm{O}_{2}$ vs. $\left.+\mathrm{Fe} /-\mathrm{H}_{2} \mathrm{O}_{2}\right)$ and oxidative $\left(+\mathrm{Fe} /+\mathrm{H}_{2} \mathrm{O}_{2}\right.$ vs. $+\mathrm{Fe} /-\mathrm{H}_{2} \mathrm{O}_{2}$ ) stress responses. Instead, the majority of the observed changes was unpredictable and was only characteristic for the combined stresses (Fig. 5). Owens et al. [74] studied the effect of $\mathrm{H}_{2} \mathrm{O}_{2}$ and gliotoxin treatments on the proteome of A. fumigatus. They could also identify several significantly differentially abundant proteins characteristic for the combined $\left(\mathrm{H}_{2} \mathrm{O}_{2}\right.$ /gliotoxin) treatments [74]. We can therefore assume that A. fumigatus successfully evolved an appropriate strategy to cope with combined iron starvation-oxidative stress. These data demonstrate that answers to single stress conditions do not necessarily reflect the behavior and capabilities in a complex habitat like the human body with versatile and even rapidly changing stress conditions. Therefore, any studies elucidating how a pathogenic microbe responds to combined stresses in the host organism in vivo are particularly fruitful [8]. Similar to the transcriptomics and proteomics data presented here, several studies in Candida albicans underlined that the adaptive responses to combinatorial stresses is not equivalent to the sum of the responses to the corresponding individual stresses [75]. In agreement with the gene expression data, growth studies confirmed that in A. fumigatus iron starvation aggravates oxidative stress susceptibility. Similar to A. fumigatus, decreased iron supply due to siderophore-deficiency decreases oxidative stress resistance in Cochliobolus heterostrophus [76]. 


\section{Changes in some medically important attributes of $A$. fumigatus}

Stress responses alter significantly the physiology of fungal cells, which may also include alterations in the virulence and/or antifungal drug susceptibility of the fungus. Both iron deprivation $\left(-\mathrm{Fe} /-\mathrm{H}_{2} \mathrm{O}_{2}\right)$ and the combined $-\mathrm{Fe} /+\mathrm{H}_{2} \mathrm{O}_{2}$ stress affected the transcription of several genes with known or putative functions in the transmembrane transport of drugs (Additional file 3). The majority of the studied drug transmembrane transport genes (17/25 genes) was up-regulated at least under one stress condition; moreover, the up-regulation of the $\mathrm{ABC}$ transporter $\mathrm{AbcB}$ protein was also observed, when the proteomes of iron-starved or combined stress-exposed cultures were analyzed (Additional file 3). Importantly, $\mathrm{AbcB}(\mathrm{Cdr} 1 \mathrm{~B})$ found to be involved in cyp51a-independent azole resistance in $A$. fumigatus [77]. The applied severe stress treatments may induce an adaptive prediction of possible environmental changes by $A$. fumigatus, similar to that presented and discussed before for Escherichia coli and $S$. cerevisiae [78]. The clinical significance of these changes may initiate further investigations, and our results support the relevance of antifungal strategies based on the inhibition of efflux systems operating in fungal cells $[79,80]$.

Iron starvation negatively affected the transcription of several genes encoding zinc and copper transporters as well (Additional file 3). These changes could simply be triggered by the reduced growth of $A$. fumigatus observed under iron deprivation or there might be an interplay between and co-regulation of the up-take and utilization of various transition metal ions in this fungus. The interplay between iron and zinc homeostasis has been demonstrated to exist in A. fumigatus by Yasmin et al. [81]. Supporting our data presented in Additional file 3, these authors demonstrated that iron starvation down-regulated $z r f B$ plasma membrane $\mathrm{Zn}^{2+}$ transporter and up-regulated $z r c A$ vacuolar $\mathrm{Zn}^{2+}$ transporter genes. Interestingly, the $\mathrm{Zn}^{2+}$ contents of iron-starved mycelia even exceeded those found in control cultures, which was attributed to the likely action of unspecific metal transporters [82]. In addition, overexpression of $z r f B$ resulted in higher zinc toxicity under iron-limited than iron-fed conditions [81]. Because the up-take and homeostasis of zinc can be promising targets in the development of new generations of antifungal drugs, a deeper understanding of the elements and regulation of zinc metabolism especially under iron-limited conditions will be an unavoidable and crucially important task in any forthcoming future studies planned to be carried out in this field [17, 81, 82].

Not surprisingly, the tested stress conditions also significantly affected the secondary metabolism (Table 4,
Additional file 4). The regulation of the secondary metabolism of fungi by various types of oxidative stress is a well-studied phenomenon [26, 83, 84]. Furthermore, the iron-dependent regulation of certain secondary metabolite gene clusters has also been described in $A$. fumigatus [85]. Nevertheless, the global regulation of the transcription of secondary metabolite gene clusters was not unambiguous in $A$. nidulans cultures subjected to various short-term oxidative stress treatments [86]. Surprisingly, only a group of the secondary metabolite biosynthetic genes responded to stress at all, and both induced and repressed clusters were detected [86]. In this study, iron starvation significantly reduced the transcriptional activity of the gliotoxin cluster, while both iron starvation and $\mathrm{H}_{2} \mathrm{O}_{2}$ treatment, up-regulated the gene clusters encoding biosynthesis of hexadehydroastechrome, fumagillin, and pseurotin A (Table 4). Both gliotoxin and fumagillin have an immune response modulator activity and, hence, influence the virulence of $A$. fumigatus [14, 87]. Meanwhile, the overproduction of hexadehydro-astechrome is also accompanied with an enhanced virulence [88]. It is important to note that harsh environmental stress conditions seem to generally down-regulate the majority of secondary metabolite gene clusters [86] and, in accordance with our previous findings, the combined iron starvation-oxidative stress did not induce the aforementioned secondary metabolite gene clusters in A. fumigatus (Table 4).

\section{Conclusions}

To confront invading pathogen microbes with combined iron starvation and oxidative stress seems to be a widespread and highly efficient strategy of the host organism to prevent the progression of infections. Nevertheless, $A$. fumigatus has the capability to reorganize its stress response system dynamically and effectively to survive complex stresses present in its habitats. In this study, we demonstrated that the adaptation of $A$. fumigatus to iron starvation combined with $\mathrm{H}_{2} \mathrm{O}_{2}$-elicited oxidative stress followed a unique pattern at the level of the transcriptome and proteome, which was basically different from those we observed in cultures solely exposed to either iron-deprivation or oxidative stress. However, our results also indicate that even successful adaptations to severe combined stresses can be fragile. Importantly, perturbations of fungal iron metabolism e.g. via exposing $A$. fumigatus to heme biosynthesis [89] or Fe-S cluster assembly $[90,91]$ inhibitors may provide us with suitable tools in future antifungal drug research to combat $A$. fumigatus infections. Although both pathways are highly conserved across taxa, some differences between human and fungi exist $[92,93]$. 


\section{Additional files}

Additional file 1: Primer pairs used in the study. (PDF 12 kb)

Additional file 2: Gene/protein enrichment analysis. Significant shared GO, FunCat or KEGG pathway terms were determined with AspGD Gene Ontology Term Finder (http://www.aspergillusgenome.org/cgi-bin/GO/ goTermFinder) or FungiFun2 (https://elbe.hki-jena.de/fungifun/ fungifun.php). Terms highlighted with yellow are presented in Tables 2 and 3. (XLS $790 \mathrm{~kb}$ )

Additional file 3: Regulation of certain gene/protein groups. Up- and down-regulated genes and proteins were defined in the Materials and methods section and were marked with red and blue colors, respectively Figures represent $\log _{2}$ FC values, whereby FC is short for "fold-change". The FC ratios were calculated for the transcriptome data based on FPKM values and for the proteome data based on ITRAQ reporter ion intensities. Results of gene/protein enrichment analysis (Fisher's exact test) are also enclosed. (XLS $210 \mathrm{~kb}$ )

Additional file 4: Regulation of secondary metabolite cluster genes and proteins. Up- and down-regulated genes and proteins were defined in the Materials and methods section and were marked with red and blue colors, respectively. Figures represent $\log _{2} \mathrm{FC}$ values, whereby $\mathrm{FC}$ is short for "fold-change". The FC ratios were calculated for the transcriptome data based on FPKM values and for the proteome data based on ITRAQ reporter ion intensities. Results of gene/protein enrichment analysis (Fisher's exact test) are also enclosed. (XLS $116 \mathrm{~kb}$ )

Additional file $\mathbf{5}$ Results of RT-qPCR measurements. Relative transcription levels were quantified with $\Delta \Delta C P=\Delta C$ Ptreated $-\Delta C P$ control. $\Delta C P$ treated $=$ CPreference gene $-C P$ tested gene measured from treated cultures. $\triangle C P$ control $=$ CPreference gene $-C$ Ptested gene measured from control cultures or from the iron depleted cultures. CP values stand for the qRT-PCR cycle numbers of crossing points. The $f k s 1$ gene was used as reference gene. qRT-PCR data are presented as the mean and S.D. data calculated from three measurements. Significantly higher or lower than 0 $\Delta \Delta C P$ values (up- or down-regulated gene) are marked with red and blue colors, respectively (Student's t-test, $p<0.05, n=3$ ). (XLS $42 \mathrm{~kb}$ )

\section{Abbreviations}

BPS: Bathophenanthroline disulfonate; CAS: Chrome azurol S;

DATS: Dimethylallyl tryptophan synthase; DCF: 2',7'-dichlorofluorescein; DCM: Dry cell mass; FPKM: Fragments per kilobase per million mapped fragments; LC-MS/MS: Liquid chromatography coupled to tandem mass spectrometry; NRPS: Non-ribosomal peptide synthases; PKS: Polyketide synthase; RIA: Reductive iron assimilation; ROS: Reactive oxygen species; RTQPCR: Reverse-transcription quantitative real-time polymerase chain reaction; SOD: Superoxide dismutase; TAF-C: triacetylfusarinine $C_{\text {; }}$ TCA

cycle: Tricarboxylic-acid cycle; TF: Transcription factors; TS: Terpene synthase

\section{Acknowledgements}

We thank Silke Steinbach and Maria Pötsch for excellent technical assistance and Matthew Blango for proofreading the text.

\section{Funding}

The research was financed by the European Union and the European Social Fund through the project EFOP-3.6.1-16-2016-00022, by the National Research, Development and Innovation Office (Hungary) - K112181 and by the Higher Education Institutional Excellence Programme of the Ministry of Human Capacities in Hungary, within the framework of the Biotechnology thematic programme of the University of Debrecen. Work in the lab of O. K. and T. K. was supported by the DFG within the Collaborative Research Centre / Transregio124 (project Z2). Working of V. K. in Jena was supported by DAAD (German Academic Exchange Service - 91529720-50015537) and by Campus Hungary (B2/1F/7506). This work was partially supported by the Austrian Science Fund/Infect-ERA program (FWF grant I1616/Infect-ERA project AspMetNet to HH). A-M.D. is an associate student of the HOROS doctoral program (W1253)

\section{Availability of data and materials}

The data sets supporting the results for this article are included within the article and supplementary data files. The full transcriptome data set is available at the Gene Expression Omnibus database (GEO; http:// www.ncbi.nlm.nih.gov/geo/) with the following accession numbers: GSE94818, GSM2484449, GSM2484453, GSM2484455, GSM2484458, GSM2484461, GSM2484465, GSM2484468, GSM2484470, GSM2484473, GSM2484476, GSM2484479 and GSM2484481. The mass spectrometry proteomics data have been deposited at the ProteomeXchange Consortium via the PRIDE [94] partner repository with the dataset identifier PXD006250.

\section{Authors' contributions}

VK: Performed transcriptomics experiments, 2',7'-dichlorofluorescin diacetate assay, RT-qPCR assays and also contributed to proteomics experiments and siderophore detection. TK: Performed proteomics experiments, provided bioinformatics support for the analysis of proteomics experiments. KA: Provided bioinformatics support for the normalization and evaluation of transcriptomics data and took part in and supervised the statistical calculations. A-MD: Analyzed the impact of oxidative stress on growth of A. fumigatus. $\mathrm{HH}$ : Took part in and supervised $A$. fumigatus growth studies, evaluated and discussed the results. IP: Coordinated the experiments, evaluated the data, discussed the results, and wrote the manuscript. OK: Took part in and supervised proteomics experiments and siderophore detection, evaluated the proteomics data, discussed the results, and wrote the manuscript. TE: Took part in and supervised transcriptomics experiments, 2',7'-dichlorofluorescin diacetate assay and RT-qPCR assays, evaluated the transcriptomics data, discussed the results and wrote the manuscript. All authors read and approved the final manuscript.

\section{Ethics approval and consent to participate}

Not applicable.

\section{Competing interests}

The authors declare that they have no competing interest.

\section{Publisher's Note}

Springer Nature remains neutral with regard to jurisdictional claims in published maps and institutional affiliations.

\section{Author details}

${ }^{1}$ Department of Biotechnology and Microbiology, Faculty of Sciences and Technology, University of Debrecen, Egyetem tér 1, Debrecen H-4032, Hungary. ${ }^{2}$ Molecular and Applied Microbiology, Leibniz Institute for Natural Product Research and Infection Biology - Hans Knöll Institute (HKI), 07745 Jena, Germany. ${ }^{3}$ Department of Zoology, Faculty of Sciences, Eszterházy Károly University, Eszterházy tér 1, Eger H-3300, Hungary. ${ }^{4}$ Division of Molecular Biology, Biocenter, Medical University of Innsbruck, A6020 Innsbruck, Austria.

Received: 7 December 2017 Accepted: 26 April 2018

Published online: 10 May 2018

\section{References}

1. Jensen HL. The fungus flora of the soil. Soil Sci. 1931;31:123-58.

2. Gugnani HC. Ecology and taxonomy of pathogenic aspergilli. Front Biosci. 2003;8:346-57.

3. Maschmeyer G, Haas A, Cornely OA. Invasive aspergillosis: epidemiology, diagnosis and management in immunocompromised patients. Drugs. 2007; 67:1567-601.

4. Park SJ, Mehrad B. Innate immunity to Aspergillus species. Clin Microbiol Rev. 2009;22:535-51.

5. Balloy $\mathrm{V}$, Chignard $\mathrm{M}$. The innate immune response to Aspergillus fumigatus. Microbes Infect. 2009;11:919-27.

6. Paulussen C, Hallsworth JE, Álvarez-Pérez S, Nierman WC, Hamill PG, Blain D, et al. Ecology of aspergillosis: insights into the pathogenic potency of Aspergillus fumigatus and some other Aspergillus species. Microb Biotechnol. 2016;10:296-322.

7. Tekaia F, Latgé JP. Aspergillus fumigatus: saprophyte or pathogen? Curr Opin Microbiol. 2005;8:385-92

8. McDonagh A, Fedorova ND, Crabtree J, Yu Y, Kim S, Chen D, et al. Subtelomere directed gene expression during initiation of invasive aspergillosis. PLoS Pathog. 2008;4:e1000154.

9. Kwon-Chung KJ, Sugui JA. Aspergillus fumigatus - what makes the species a ubiquitous human fungal pathogen? PLoS Pathog. 2013;9:e1003743. 
10. Abad A, Fernández-Molina JV, Bikandi J, Ramírez A, Margareto J, Sendino J, et al. What makes Aspergillus fumigatus a successful pathogen? Genes and molecules involved in invasive aspergillosis. Rev Iberoam Micol. 2010;27: $155-82$.

11. Aimanianda V, Bayry J, Bozza S, Kniemeyer O, Perruccio K, Elluru SR, et al. Surface hydrophobin prevents immune recognition of airborne fungal spores. Nature. 2009;460:1117-21.

12. Heinekamp T, Thywißen A, Macheleidt J, Keller S, Valiante V, Brakhage AA. Aspergillus fumigatus melanins: interference with the host endocytosis pathway and impact on virulence. Front Microbiol. 2013;3:440.

13. Gresnigt MS, Bozza S, Becker KL, Joosten LA, Abdollahi-Roodsaz $\mathrm{S}$, van der Berg WB, et al. A polysaccharide virulence factor from Aspergillus fumigatus elicits anti-inflammatory effects through induction of Interleukin-1 receptor antagonist. PLoS Pathog. 2014;10:e1003936.

14. Scharf DH, Heinekamp T, Remme N, Hortschansky P, Brakhage AA, Hertweck C. Biosynthesis and function of gliotoxin in Aspergillus fumigatus. Appl Microbiol Biotech. 2012:93:467-72.

15. Binder U, Lass-Flörl C. New insights into invasive aspergillosis - from the pathogen to the disease. Curr Pharm Des. 2013;19:3679-88.

16. Haas H. Iron - a key nexus in the virulence of Aspergillus fumigatus. Front Microbiol. 2012;3:28

17. Amich J, Calera JA. Zinc acquisition: a key aspect in Aspergillus fumigatus virulence. Mycopathologia. 2014;178:379-85.

18. Wiemann P, Perevitsky A, Lim FY, Shadkchan Y, Knox BP, Landero Figueora $J A$, et al. Aspergillus fumigatus copper export machinery and reactive oxygen intermediate defense counter host copper-mediated oxidative antimicrobial offense. Cell Rep. 2017;19:2174-6.

19. Cai Z, Du W, Zeng Q, Long N, Dai C, Lu L. Cu-sensing transcription factor Mac1 coordinates with the Ctr transporter family to regulate cu acquisition and virulence in Aspergillus fumigatus. Fungal Genet Biol. 2017;107:31-43.

20. Hillmann F, Bagramyan K, Straßburger M, Heinekamp T, Hong TB, Bzymek $\mathrm{KP}$, et al. The crystal structure of peroxiredoxin asp $\mathrm{f3}$ provides mechanistic insight into oxidative stress resistance and virulence of Aspergillus fumigatus. Sci Rep. 2016;6:33396.

21. Hagiwara D, Suzuki S, Kamei K, Gonoi T, Kawamoto S. The role of AtfA and HOG MAPK pathway in stress tolerance in conidia of Aspergillus fumigatus. Fungal Genet Biol. 2014;73:138-49.

22. Altwasser R, Baldin C, Weber J, Guthke R, Kniemeyer O, Brakhage AA, et al. Network modeling reveals cross talk of MAP kinases during adaptation to caspofungin stress in Aspergillus fumigatus. PLoS One. 2015;10:e0136932.

23. Brandon M, Howard B, Lawrence C, Laubenbacher R. Iron acquisition and oxidative stress response in Aspergillus fumigatus. BMC Syst Biol. 2015;9:19.

24. Pereira Silva L, Alves de Castro P, Reis TF, Paziani MH, Von Zeska Kress MR, Riaño-Pachón DM, et al. Genome-wide transcriptome analysis of Aspergillus fumigatus exposed to osmotic stress reveals regulators of osmotic and cell wall stresses that are SakA ${ }^{\text {HOG } 1}$ and MpkC dependent. Cell Microbiol. 2016; https://doi.org/10.1111/cmi.12681.

25. Albrecht D, Guthke R, Brakhage AA, Kniemeyer O. Integrative analysis of the heat shock response in Aspergillus fumigatus. BMC Genomics. 2010;11:32-49.

26. Fréalle E, Aliouat-Denis CM, Delhaes L, Hot D, Dei-Cas E. Transcriptomic insights into the oxidative response of stress-exposed Aspergillus fumigatus. Curr Pharm Des. 2013;19:3713-37.

27. Kroll K, Pähtz V, Hillmann F, Vaknin Y, Schmidt-Heck W, Roth M, et al. Identification of hypoxia-inducible target genes of Aspergillus fumigatus by transcriptome analysis reveals cellular respiration as an important contributor to hypoxic survival. Eukaryot Cell. 2014;13:1241-53.

28. Irmer H, Tarazona S, Sasse C, Olbermann P, Loeffler J, Krappmann S, et al. RNAseq analysis of Aspergillus fumigatus in blood reveals a just wait and see resting stage behavior. BMC Genomics. 2015;16:640.

29. Brown NA, Goldman GH. The contribution of Aspergillus fumigatus stress responses to virulence and antifungal resistance. J Microbiol. 2016;54:243-53.

30. Schrettl M, Bignell E, Kragl C, Joechl C, Rogers T, Arst HN Jr, et al. Siderophore biosynthesis but not reductive iron assimilation is essential for Aspergillus fumigatus virulence. J Exp Med. 2004;200:1213-9.

31. Hissen AH, Chow JM, Pinto LJ, Moore MM. Survival of Aspergillus fumigatus in serum involves removal of iron from transferrin: the role of siderophores. Infect Immun. 2004;72:1402-8.

32. Haas $H$, Eisendle M, Turgeon BG. Siderophores in fungal physiology and virulence. Annu Rev Phytopathol. 2008;46:149-87.

33. Moore MM. The crucial role of iron uptake in Aspergillus fumigatus virulence Curr Opin Microbiol. 2013;16:692-9.
34. Park YS, Kim JY, Yun CW. Identification of ferrichrome- and ferrioxamine B-mediated iron uptake by Aspergillus fumigatus. Biochem J. 2016;473: 1203-13.

35. Schrettl M, Beckmann N, Varga J, Heinekamp T, Jacobsen ID, Jochl C, et al. HapX-mediated adaption to iron starvation is crucial for virulence of Aspergillus fumigatus. PLoS Pathog. 2010;6:1001124.

36. Lessing F, Kniemeyer O, Wozniok I, Loeffler J, Kurzai O, Haertl A, et al. The Aspergillus fumigatus transcriptional regulator AfYap1 represents the major regulator for defense against reactive oxygen intermediates but is dispensable for pathogenicity in an intranasal mouse infection model. Eukaryot Cell. 2007;6:2290-302.

37. Lamarre C, Ibrahim-Granet O, Du C, Calderone R, Latgé JP. Characterization of the SKN7 ortholog of Aspergillus fumigatus. Fungal Genet Biol. 2007;44:682-90.

38. Valiante $V$, Heinekamp $T$, Jain $R$, Härtl A, Brakhage AA. The mitogenactivated protein kinase MpkA of Aspergillus fumigatus regulates cell wall signaling and oxidative stress response. Fungal Genet Biol. 2008;45:618-27.

39. Bruder Nascimento AC, Dos Reis TF, de Castro PA, Hori Jl, Bom VL, de Assis LJ, et al. Mitogen activated protein kinases SakA(HOG1) and MpkC collaborate for Aspergillus fumigatus virulence. Mol Microbiol. 2016;100:841-59.

40. Woodworth RC, Richter GW. Iron-dependent enzymes in mammalian systems. In: Ponka P, Schulman HM, editors. Iron transport and storage; 1990. p. 17-39.

41. Dlouhy AC, Outten CE. The iron metallome in eukaryotic organisms. Met Ions Life Sci. 2013;12:241-78.

42. Prüfer $S$, Weber $M$, Stein $P$, Bosmann $M$, Stassen M, Kreft A, et al. Oxidative burst and neutrophil elastase contribute to clearance of Aspergillus fumigatus pneumonia in mice. Immunobiology. 2014;219:87-96.

43. Zarember KA, Sugui JA, Chang YC, Kwon-Chung KJ, Gallin Jl. Human polymorphonuclear leukocytes inhibit Aspergillus fumigatus conidial growth by lactoferrin-mediated iron depletion. J Immunol. 2007;178:6367-73.

44. Haider S, Pal R. Integrated analysis of transcriptomic and proteomic data. Curr Genomics. 2013;14:91-110

45. Barratt RW, Johnson GB, Ogata WN. Wild-type and mutant stocks of Aspergillus nidulans. Genetics. 1965;52:233-46.

46. Sámi L, Emri T, Pócsi I. Autolysis and aging of Penicillium chrysogenum cultures under carbon starvation: III: glutathione metabolism and formation of reactive oxygen species. Mycol Res. 2001;105:1246-50.

47. Machuca A, Milagres AM. Use of CAS-agar plate modified to study the effect of different variables on the siderophore production by Aspergillus. Lett Appl Microbiol. 2003;36:177-81.

48. Chomczynski P. A reagent for the single-step simultaneous isolation of RNA, DNA and proteins from cell and tissue samples. BioTechniques. 1993;15:536-7.

49. Zs K, Szarka M, Kovács S, Boczonádi I, Emri T, Abe K, et al. Effect of cell wall integrity stress and RImA transcription factor on asexual development and autolysis in Aspergillus nidulans. Fungal Genet Biol. 2013;54:1-14.

50. Trapnell C, Pachter L, Salzberg SL. TopHat: discovering splice junctions with RNA-Seq. Bioinformatics. 2009:25:1105-11.

51. Trapnell C, Hendrickson DG, Sauvageau M, Goff L, Rinn JL, Pachter L. Differential analysis of gene regulation at transcript resolution with RNA-seq Nat Biotechnol. 2013;31:46-53.

52. Baldin $C$, Valiante $V$, Krüger $T$, Schafferer $L$, Haas $H$, Kniemeyer $O$, et al. Comparative proteomics of a tor inducible Aspergillus fumigatus mutant reveals involvement of the Tor kinase in iron regulation. Proteomics. 2015; 15:2230-43.

53. Priebe $\mathrm{S}$, Kreisel $\mathrm{C}$, Horn F, Guthke R, Linde J. FungiFun2: a comprehensive online resource for systematic analysis of gene lists from fungal species. Bioinformatics. 2015;31:445-6.

54. Cerqueira GC, Arnaud MB, Inglis DO, Skrzypek MS, Binkley G, Simison M, et al. The Aspergillus genome database: multispecies curation and incorporation of RNA-Seq data to improve structural gene annotations. Nucleic Acids Res. 2014;42:D705-10.

55. Flipphi M, Sun J, Robellet X, Karaffa L, Fekete E, Zeng AP, et al. Biodiversity and evolution of primary carbon metabolism in Aspergillus nidulans and other Aspergillus spp. Fungal Genet Biol. 2009;46(Suppl 1):S19-44.

56. Alcazar-Fuoli L, Mellado E. Ergosterol biosynthesis in Aspergillus fumigatus: its relevance as an antifungal target and role in antifungal drug resistance. Front Microbiol. 2013;3:439.

57. Inglis DO, Binkley J, Skrzypek MS, Arnaud MB, Cerqueira GC, Shah P, et al. Comprehensive annotation of secondary metabolite biosynthetic genes and 
gene clusters of Aspergillus nidulans, A. fumigatus, A. niger and A. oryzae. BMC Microbiol. 2013;13:91.

58. Lin HC, Chooi YH, Dhingra S, Xu W, Calvo AM, Tang Y. The fumagillin biosynthetic gene cluster in Aspergillus fumigatus encodes a cryptic terpene cyclase involved in the formation of $\beta$-trans-bergamotene. J Am Chem Soc. 2013;135:4616-9.

59. Haas H. Fungal siderophore metabolism with a focus on Aspergillus fumigatus. Nat Prod Rep. 2014;31:1266-76.

60. Yasmin S, Alcazar-Fuoli L, Gründlinger M, Puempel T, Cairns T, Blatzer M, et al. Mevalonate governs interdependency of ergosterol and siderophore biosyntheses in the fungal pathogen Aspergillus fumigatus. Proc Natl Acad Sci U S A. 2012;109:E497-504.

61. Blatzer $\mathrm{M}$, Binder $\mathrm{U}$, Haas $\mathrm{H}$. The metalloreductase FreB is involved in adaptation of Aspergillus fumigatus to iron starvation. Fungal Genet Biol. 2011:48:1027-33

62. Schrettl M, Kim HS, Eisendle M, Kragl C, Nierman WC, Heinekamp T, et al. SreA-mediated iron regulation in Aspergillus fumigatus. Mol Microbiol. 2008; 70:27-43.

63. Wong Sak Hoi J, Lamarre C, Beau R, Meneau I, Berepiki A, Barre A, et al. A novel family of dehydrin-like proteins is involved in stress response in the human fungal pathogen Aspergillus fumigatus. Mol Biol Cell. 2011;22:1896-906.

64. Hortschansky P, Eisendle M, Al-Abdallah Q, Schmidt AD, Bergmann S, Thön $M$, et al. Interaction of HapX with the CCAAT-binding complex - a novel mechanism of gene regulation by iron. EMBO J. 2007;26:3157-68.

65. Miao R, Holmes-Hampton GP, Lindahl PA. Biophysical investigation of the iron in Aft1-1 (up) and gal-YAH1 Saccharomyces cerevisiae. Biochemistry. 2011;50:2660-71

66. Kispal G, Sipos K, Lange H, Fekete Z, Bedekovics T, Janáky T, et al. Biogenesis of cytosolic ribosomes requires the essential iron-Sulphur protein Rli1p and mitochondria. EMBO J. 2005;24:589-98.

67. Oberegger H, Zadra I, Schoeser M, Haas H. Iron starvation leads to increased expression of cu/Zn-superoxide dismutase in Aspergillus. FEBS Lett. 2000;485:113-6.

68. Fridovich I. Superoxide radical and superoxide dismutases. Annu Rev Biochem. 1995;64:97-112.

69. Roetzer A, Klopf E, Gratz N, Marcet-Houben M, Hiller E, Rupp S, et al. Regulation of Candida glabrata oxidative stress resistance is adapted to host environment. FEBS Lett. 2011:585:319-27.

70. Imlay JA. Iron-Sulphur clusters and the problem with oxygen. Mol Microbiol. 2006:59:1073-82.

71. Szilágyi M, Miskei M, Karányi Z, Lenkey B, Pócsi I, Emri T. Transcriptome changes initiated by carbon starvation in Aspergillus nidulans. Microbiology. 2013;159:176-90

72. van Munster J, Burggraaf A, Pócsi I, Szilágyi M, Emri T, Ram A. Post-genomic approaches to dissect carbon starvation responses in aspergilli. In: de Vries RP, Gelber IB, Andersen MR, editors. Aspergillus and Penicillium in the postgenomic era. 2016. 89-111.

73. Richie DL, Fuller KK, Fortwendel J, Miley MD, McCarthy JW, Feldmesser M, et al. Unexpected link between metal ion deficiency and autophagy in Aspergillus fumigatus. Eukaryot Cell. 2007;6:2437-47.

74. Owens RA, Hammel S, Sheridan KJ, Jones GW, Doyle S. A proteomic approach to investigating gene cluster expression and secondary metabolite functionality in Aspergillus fumigatus. PLoS One. 2014;9:e106942.

75. Brown AJ, Budge S, Kaloriti D, Tillmann A, Jacobsen MD, Yin Z, et al. Stress adaptation in a pathogenic fungus. J Exp Biol. 2014:217:144-55

76. Oide S, Moeder W, Krasnoff S, Gibson D, Haas H, Yoshioka K, et al. NPS6, encoding a nonribosomal peptide synthetase involved in siderophoremediated iron metabolism, is a conserved virulence determinant of plant pathogenic ascomycetes. Plant Cell. 2006;18:2836-53.

77. Fraczek MG, Bromley M, Buied A, Moore CB, Rajendran R, Rautemaa R, et al. The cdr1B efflux transporter is associated with non-cyp51a-mediated itraconazole resistance in Aspergillus fumigatus. J Antimicrob Chemother. 2013;68:1486-96.

78. Mitchell A, Romano GH, Groisman B, Yona A, Dekel E, Kupiec M, et al. Adaptive prediction of environmental changes by microorganisms. Nature. 2009;460:220-4.

79. Cannon RD, Lamping E, Holmes AR, Niimi K, Baret PV, Keniya MV, et al. Efflux-mediated antifungal drug resistance. Clin Microbiol Rev. 2009;22:291-321.

80. Tegos GP, Haynes M, Strouse JJ, Khan MM, Bologa CG, Oprea TI, et al. Microbial efflux pump inhibition: tactics and strategies. Curr Pharm Des. 2011;17:1291-302.
81. Yasmin S, Abt B, Schrettl M, Moussa TA, Werner ER, Haas H. The interplay between iron and zinc metabolism in Aspergillus fumigatus. Fungal Genet Biol. 2009;46:707-13.

82. Vicentefranqueira $R$, Amich J, Laskaris $\mathrm{P}$, Ibrahim-Granet $\mathrm{O}$, Latgé JP, Toledo $\mathrm{H}$, et al. Targeting zinc homeostasis to combat Aspergillus fumigatus infections. Front Microbiol. 2015;6:160.

83. Hong SY, Roze LV, Wee J, Linz JE. Evidence that a transcription factor regulatory network coordinates oxidative stress response and secondary metabolism in aspergilli. Microbiology. 2013;22:144-60.

84. Montibus M, Pinson-Gadais L, Richard-Forget F, Barreau C, Ponts N. Coupling of transcriptional response to oxidative stress and secondary metabolism regulation in filamentous fungi. Crit Rev Microbiol. 2015;41:295-308.

85. Wiemann P, Lechner BE, Baccile JA, Velk TA, Yin WB, Bok JW, et al. Perturbations in small molecule synthesis uncovers an iron-responsive secondary metabolite network in Aspergillus fumigatus. Front Microbiol. 2014;5:530.

86. Emri T, Szarvas V, Orosz E, Antal K, Park H, Han KH, et al. Core oxidative stress response in Aspergillus nidulans. BMC Genomics. 2015;16:478.

87. Fallon JP, Reeves EP, Kavanagh K. The Aspergillus fumigatus toxin fumagillin suppresses the immune response of Galleria mellonella larvae by inhibiting the action of haemocytes. Microbiology. 2011;157:1481-8.

88. Yin WB, Baccile JA, Bok JW, Chen Y, Keller NP, Schroeder FC. A nonribosomal peptide synthetase-derived iron(III) complex from the pathogenic fungus Aspergillus fumigatus. J Am Chem Soc. 2013;135:2064-7.

89. Ben Yaakov D, Rivkin A, Mircus G, Albert N, Dietl AM, Kovalerchick D, et al. Identification and characterization of haemofungin, a novel antifungal compound that inhibits the final step of haem biosynthesis. J Antimicrob Chemother. 2016;71:946-52.

90. Choby JE, Mike LA, Mashruwala AA, Dutter BF, Dunman PM, Sulikowski GA, et al. A small-molecule inhibitor of iron-sulfur cluster assembly uncovers a link between virulence regulation and metabolism in Staphylococcus aureus. Cell Chem Biol. 2016;23:1351-61.

91. Tripathi SK, XU T, Feng Q, Avula B, Shi X, Pan X, et al. Two plant-derived aporphinoid alkaloids exert their antifungal activity by disrupting mitochondrial iron-sulfur cluster biosynthesis. J Biol Chem. 2017:292:16578-93.

92. Braymer JJ, Lill R. Iron-sulfur cluster biogenesis and trafficking in mitochondria. J Biol Chem. 2017:292:12754-63.

93. Kroll K, Shekhova E, Mattern DJ, Thywissen A, Jacobsen ID, Strassburger M, et al. The hypoxia-induced dehydrogenase HorA is required for coenzyme Q10 biosynthesis, azole sensitivity and virulence of Aspergillus fumigatus. Mol Microbiol. 2016;101:92-108.

94. Vizcaíno JA, Csordas A, del-Toro N, Dianes JA, Griss J, Lavidas I, et al. 2016 update of the PRIDE database and related tools. Nucleic Acids Res. 2016; 44(D1):D447-56.

Ready to submit your research? Choose BMC and benefit from

- fast, convenient online submission

- thorough peer review by experienced researchers in your field

- rapid publication on acceptance

- support for research data, including large and complex data types

- gold Open Access which fosters wider collaboration and increased citations

- maximum visibility for your research: over $100 \mathrm{M}$ website views per year

At BMC, research is always in progress.

Learn more biomedcentral.com/submissions 